\title{
Innovative Enterprise Solves the Agency Problem: The Theory of the Firm, Financial Flows, and Economic Performance
}

\author{
William Lazonick ${ }^{* \#}$
}

Working Paper No. 62

August 28, 2017

\begin{abstract}
Since the late 1980s, the dominant ideology of corporate governance in the United States has been that, for the sake of superior economic performance, companies should "maximize shareholder value" (MSV). As promulgated by agency theorists, however, MSV is an ideology of value extraction that lacks a theory of value creation. As a theory of value creation, I have constructed "The Theory of Innovative Enterprise" - an analytical framework for understanding how a business enterprise can generate a good or service that is of higher quality and lower cost than products previously available. In this essay, I use innovation theory to provide both a general theoretical critique and a selective empirical critique of agency theory. In Section 2, reviewing Bebchuk and Fried, Pay Without Performance (2004), I argue that the authors fail in their objective to demonstrate that U.S.-style stock-based pay undermines "shareholder value," while I contend that, from the perspective of innovation theory, shareholder value is an illegitimate measure of corporate performance. In Section 3, focusing on Bebchuk, Brav, and

\footnotetext{
* University of Massachusetts, Lowell and The Academic Research Network;

Thinking and the Gatsby Foundation. I am grateful to Tom Ferguson, Matt Hopkins, Ken Jacobson, and Jang-Sup Shin for their insightful comments.
}

william.lazonick@gmail.com

\# Funding for the research summarized in this paper was provided by the Institute for New Economic
\end{abstract}


Jiang, "The Long-Term Effects of Hedge-Fund Activism" (2015), which purports to demonstrate empirically that the exercise of shareholder power improves corporate operating performance, return on assets, and stock returns over periods of as long as five years, I argue that innovation theory casts serious doubt on their findings because the supposed long-term improvements in corporate performance could very well have resulted from cost-cutting that increased profits at the expense of the labor force rather than from productivity gains from the generation of higher quality products at lower unit costs - gains of innovative enterprise that are typically shared with the firm's employees. In Section 4, I turn to a step-by-step critique of Fried and Wang, "ShortTermism and Capital Flows" (2017), which, taking issue with the central argument in my article "Profits Without Prosperity" (2104) that massive distributions to shareholders in the forms of dividends and buybacks have come at the expense of investment in innovation and higher wages, claims that a number of other sources of funds (debt issues, stock issues) and uses of funds (remuneration, R\&D, acquisitions, venture capital) result in innovation and good wages. I demonstrate that Fried and Wang make a series of assertions about the economic impacts of financial flows - which they incorrectly call "capital flows"- that lack substance. I conclude the essay by arguing that, for analyzing the operation and performance of the economy, innovation theory should replace agency theory. Agency theorists do not address, let alone explain, why since the 1980s, the United States has experienced extreme concentration of income among the richest households and the erosion of middle-class employment opportunities. I contend that the ideology that corporations should be run to "maximize shareholder value" as promulgated by agency theorists has contributed to inferior economic performance. I argue that the critical issue for understanding the role of corporate governance in supporting or undermining economic performance is the relation between value creation and value extraction for those "stakeholders" engaged in the development and utilization of the company's productive capabilities. Innovative enterprise solves the agency problem. By incentivizing and rewarding the real value creators, the innovative enterprise can mobilize the skill, effort, and finance that, by generating high-quality, low-cost products, can improve the performance of the economy-defined in terms of stable and equitable economic growth.

JEL Codes: D2, D3, D8, G3, L2, O3

Keywords: Innovation theory, agency theory, maximize shareholder value (MSV), stock buybacks, value creation, value extraction, corporate governance, shareholder value ideology. 


\section{Innovation Theory Versus Agency Theory}

Since the late 1980s, the dominant ideology of corporate governance in the United States has been that, for the sake of superior economic performance, companies should "maximize shareholder value" (MSV). MSV ideology is rooted in two misconceptions of the role of public shareholders in the U.S. business corporation. The most fundamental error is the assumption that public shareholders invest in the productive assets of the corporation. They do not. ${ }^{1}$ They allocate their savings to the purchase of shares that are outstanding on the stock market, and they are willing to do so because the liquidity of the market enables them to sell those financial assets at any time they so choose.

The erroneous MSV assumption that public shareholders invest in the productive assets of the company is then compounded by the fallacy that it is only public shareholders who make risky investments in the corporation's productive assets, and hence that it is only shareholders who have a claim on the corporation's profits, if and when they occur. The basis for critiquing this fundamental assumption of MSV, referred to as "shareholder primacy," is the reality of the value-creation process occurring within business enterprises, which enables them to produce goods and services that buyers need or want at prices that they are able or willing to pay. Specifically, through the value-creation process, households in their capacities of both workers and taxpayers take risks in making investments in the productive capabilities of the innovative business enterprise. ${ }^{2}$

In supplying their skills and efforts to the process of generating innovative products that, if successful, can create value in the future, workers take the risk that, because of technological, market, or competitive uncertainties, the application of their skills and the expenditure of their efforts will be in vain. Far from reaping expected gains in the forms of higher pay, more job security, superior benefits, and better work conditions, workers may face cuts in pay and benefits if the firm's innovation investment strategy does not succeed, and they may even find themselves laid off. Workers also face the possibility that, even if the innovation process is successful, the institutional environment in which MSV prevails will empower corporate executives to cut some workers' wages and lay off others in order to extract value for shareholders, including themselves, that those workers helped to create.

In financing investments in infrastructure and knowledge, taxpayers make productive capabilities available to business enterprises, but with no guaranteed return on those investments. No matter the corporate tax rate, households as taxpayers face the risks that, because of technological, market, and competitive uncertainties, the enterprise will not generate the profits that provide business-tax revenues as a return to households as taxpayers on their investments in infrastructure and knowledge. Moreover, tax rates are politically determined. Households as taxpayers face the political uncertainty that predatory value extractors - financial interests who

1 William Lazonick, "The Functions of the Stock Market and the Fallacies of Shareholder Value," Institute for New Economic Thinking Working Paper No. 58, June 3, 2017 (revised July 20, 2017), at https://www.ineteconomics.org/research/researchpapers/the-functions-of-the-stock-market-and-the-fallacies-of-shareholder-value

2 William Lazonick, "Innovative Enterprise or Sweatshop Economics? In Search of Foundations of Economic Analysis," Challenge, 59, 2, 2016: 65-114. For a penetrating critique of MSV by a legal scholar, see Lynn Stout, The Shareholder Value Myth: How Putting Shareholders First Harms Investors, Corporations, and the Public, Berrett-Koehler Publishers, 2012. 
"take" far more than they "make"3 - may convince government policy-makers that unless businesses are given tax cuts or financial subsidies that will permit adequate profits, they will not be able to make value-creating investments. Politicians may be put in power who accede to these demands.

Given MSV's assumptions, the basic policy conclusion put forth by its proponents, known in the academic world as "agency theorists," is that a company should distribute what they deem to be its "free cash flow" to public shareholders. Those holding onto their shares will receive cash dividends, while those wishing to sell their shares will stand a chance of reaping enhanced capital gains as higher stock prices are achieved through stock repurchases - if they are able to get the timing of the stock sales right. The assumption is that, via financial markets, shareholders will then reallocate at least a portion of their gains from dividends and stock sales to uses that are more "efficient" than those to which they would have been put had the funds been retained by the company.

MSV implies that shareholders derive their gains by extracting value as a reward for taking the risk of contributing to processes that create value. Thus, when corporations pay dividends or do repurchases (aka buybacks), MSV characterizes these distributions as "returning" capital to shareholders. For example, from 2012 through the second quarter of 2017 Apple spent \$151 billion on buybacks and \$54 billion on dividends under its "Capital Return Program." "Yet the only time in its history that Apple ever raised funds on the public stock market was in 1980, when it collected $\$ 97$ million in its initial public offering (IPO). ${ }^{5}$ How can a corporation return capital to parties that never supplied it with capital? The vast majority of those who hold Apple's publicly listed shares have simply bought outstanding shares on the stock market. They have contributed nothing to Apple's value-creating capabilities.

MSV is an ideology of value extraction, and the "free" in free cash flow is an ideologically loaded concept. Proponents of MSV may accept that a company needs to retain some cash flow to maintain the functioning of its physical capital, but they generally view labor as an interchangeable commodity whose services can be hired, and fired, as needed on the labor market. And they typically ignore the contributions that households as taxpayers make to business-value creation. Rooted in the neoclassical theory of the market economy, MSV assumes that markets, not organizations, allocate resources to their most efficient uses. Yet it is organizations-including not only businesses enterprises, but also government agencies and family households - that make the investments in productive capabilities that determine both the

3 See Rana Foroohar, Makers and Takers: The Rise of Finance and the Fall of American Business, Crown Business, 2016.

4 Roger Fingas, “Apple to increase capital return program by \$50B, extended for full year," Applelnsider, May 2, 2017, at http://appleinsider.com/articles/17/05/02/apple-to-boost-capital-return-program-by-50b-extended-for-full-year; Apple Inc., "Return of Capital and Cash Position," Press Release, at http://files.shareholder.com/downloads/AAPL/4402228650x0x840254/7137D28C-2E6E-4406-8435ADAB52BB6F4C/Return_of_Capital_Timeline_Q217.pdf

5 William Lazonick, "Numbers show Apple shareholders have already gotten plenty," Harvard Business Review, October 16, 2014, at https://hbr.org/2014/10/numbers-show-apple-shareholders-have-already-gotten-plenty. See also William Lazonick, Matt Hopkins, and Ken Jacobson, "What we learn about inequality from Carl Icahn's \$2 billion 'no brainer'," Institute For New Economic Thinking Perspectives, June 6, 2106, at https://www.ineteconomics.org/perspectives/blog/what-we-learnabout-inequality-from-carl-icahns-2-billion-apple-no-brainer. 
"most efficient" uses that exist at a given point in time and the extent to which those "most efficient" uses become more productive over time. ${ }^{6}$

At the core of a theory of value creation is what I call "The Theory of Innovative Enterprise"an analytical framework for understanding how a business enterprise can generate a good or service that is of higher quality and lower cost than products previously available. ${ }^{7}$ The innovation process that can generate these outcomes is:

- Uncertain: When investments in transforming technologies and accessing markets are made, the product and financial outcomes cannot be known. Hence the need for strategy.

- Collective: To generate higher-quality, lower-cost products, the enterprise must integrate the skills and efforts of large numbers of people with different responsibilities and capabilities into the learning processes that are the essence of innovation. Hence the need for organization.

- Cumulative: Collective learning today enables collective learning tomorrow, and these organizational learning processes must be sustained continuously over time until, through the sale of innovative products, financial returns can be generated. Hence the need for finance.

The Theory of Innovative Enterprise identifies three social conditions-strategic control, organizational integration, and financial commitment - that can enable the firm to manage the uncertain, collective, and cumulative character of the innovation process.

- Strategic control: For innovation to occur in the face of technological, market, and competitive uncertainties, executives who control corporate resource allocation must have the abilities and incentives to make strategic investments in innovation. Their abilities depend on their knowledge of how strategic investments in new capabilities can enhance the enterprise's existing capabilities. Their incentives depend on alignment of their personal interests with the company's purpose of generating innovative products.

- Organizational integration: The implementation of an innovation strategy requires integration of people working in a complex division of labor into the collective and cumulative learning processes that are the essence of innovation. Work satisfaction, promotion, remuneration, and benefits are important instruments in a reward system that motivates and empowers employees to engage in collective learning over a sustained period of time.

- Financial commitment: For collective learning to cumulate over time, the sustained commitment of "patient capital" must keep the learning organization intact. For a startup company, venture capital can provide financial commitment. For a going concern, retained earnings (leveraged, if need be, by debt issues) are the foundation of financial commitment.

The Theory of Innovative Enterprise explains how, in twentieth-century America, a "retain-andreinvest" allocation regime enabled a relatively small number of business enterprises in a wide range of industries to grow to employ tens, or even hundreds, of thousands of people and attain

\footnotetext{
6 Lazonick, "Innovative Enterprise or Sweatshop Economics?" and references therein.

7 William Lazonick, "The Theory of Innovative Enterprise: Foundation of Economic Analysis," AIR Working Paper, August 2015, at www.theAIRnet.org.
} 
dominant product-market shares. ${ }^{8}$ Companies retained corporate profits and reinvested them in productive capabilities, including first and foremost collective and cumulative learning. Companies integrated personnel into learning processes through career employment. Into the 1980 s, and in some cases beyond, the norm of a career-with-one-company prevailed at major U.S. corporations. A steady stream of dividend income and the prospect of higher future stock prices based on innovative products gave shareholders an interest in "retain-and-reinvest."

From the 1960s, however, a changing business environment encouraged executives of established U.S. corporations to shift corporate resource allocation from "retain-and reinvest" to "downsize-and-distribute." By the 1980s, even in good times companies began to downsize their labor forces and to distribute more profits to shareholders. Agency theory, with its MSV ideology, and the neoclassical theory of the market economy that underpins it, bear prime responsibility for legitimizing processes of predatory value extraction that, since the 1970s, have concentrated income among the richest households in the United States while leaving most Americans worse off. ${ }^{10}$

In the 1970 s and 1980 s, agency theory emerged as a new branch of neoclassical economics to justify, and subsequently enable, this dramatic transformation in corporate resource allocation and its economic outcomes. ${ }^{11}$ Agency theory derives its name from the notion that public shareholders as "principals" have to rely on corporate executives as "agents" to manage corporate resources and that, from these positions of power, corporate executives will seek to build their own empires and pad their own bank accounts rather than run the corporation for the sake of its presumed principals. One way of solving this "agency problem" is through what agency theorists call the "market for corporate control," which seeks to use voting rights connected with shareholding to oust corporate executives who ignore the interests of shareholders. In practice, "the market for corporate control" takes the form of proxy contests that seek to replace board members and senior executives.

But even if it were accurate to view shareholders as principals who are reliant on senior executives as agents to manage the corporation, the agency problem might not be solved by firing one set of senior executives and replacing it with another set. The need for "agency" would nonetheless remain. The complete solution to the agency problem requires that the incentives of

\footnotetext{
8 Over the last century, large corporations have dominated the US economy. In 2012, the 1,909 companies with 5,000 or more employees in the United States were only 0.03 percent of all firms, but, with an average employment of 20,366, employed 34 percent of the U.S. business-sector labor force while covering 38 percent of all payroll expenditures and generating 44 percent of all revenues. United States Census Bureau, "Statistics of U.S. Businesses (SUSB)," Data on "2012 SUSB Annual Data Tables by Establishment Industry" at https://www.census.gov/data/tables/2012/econ/susb/2012-susb-annual.html. The most recent data for 2014 (which do not include revenues) show that 1,986 firms with 5,000 or more employees had slightly larger shares of establishments, employees, and payrolls than this employment category of firms in 2012: https://www.census.gov/data/tables/2014/econ/susb/2014-susb-annual.html

9 William Lazonick and Mary O'Sullivan, “Maximizing Shareholder Value: A New Ideology for Corporate Governance," Economy and Society, 29, 1, 2000: 13-35.

10 William Lazonick, "Labor in the Twenty-First Century: The Top $0.1 \%$ and the Disappearing Middle Class," in Christian E. Weller, ed., Inequality, Uncertainty and Opportunity: The Varied and Growing Role of Finance in Labor Relations, Cornell University Press, 2015: 143-192.

11 Michael C. Jensen and William H. Meckling, "Theory of the Firm: Managerial Behavior, Agency Costs, and Ownership Structure," Journal of Financial Economics, 3, 4, 1976: 305-360; Michael C. Jensen, "Agency Costs of Free Cash Flow, Corporate Finance, and Takeovers," American Economic Review, 76, 2, 1986: 323-329.
} 
senior executives be aligned with those of public shareholders. What better way to do so than by rewarding executives with stock-based pay? ${ }^{12}$

Indeed, it is stock-based pay that since the 1980s has come to dominate the remuneration of the executives of major U.S. corporations. ${ }^{13}$ Figure 1 shows data on the mean total direct compensation and its components for the 500 highest-paid executives named in proxy statements that publicly listed companies filed with the Securities and Exchange Commission (SEC) and that were included in the S\&P ExecuComp database for each year from 2006 through 2015. Total compensation of the top 500 ranged from an average of $\$ 15.9$ million in 2009, with 60 percent from stock-based pay, to $\$ 32.6$ million in 2015, with 82 percent from stock-based pay.

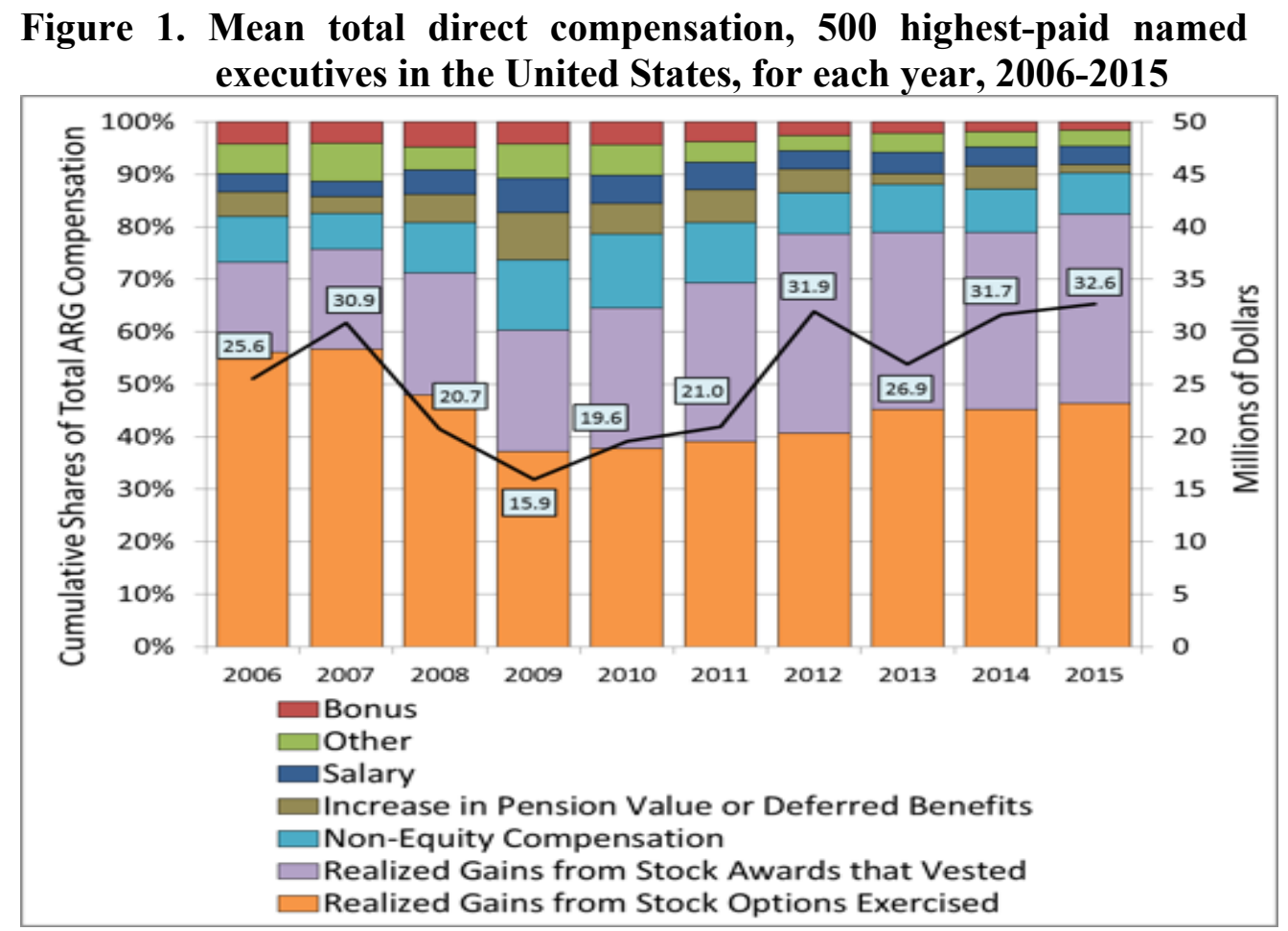

Source: S\&P ExecuComp database (calculations by Matt Hopkins, The Academic-Industry Research Network).

Incentivized by stock-based pay, since the last half of the 1980s senior corporate executives have embraced MSV ideology, as manifested in massive payouts to shareholders in the forms of both cash dividends and stock buybacks. Figure 2 shows net equity issues (new stock issues less stock taken off the market through stock repurchases and M\&A activity) of U.S. financial and nonfinancial corporations from 1946 through 2016. Over the decade 2007-2016 net equity issues of nonfinancial corporations averaged $-\$ 412$ billion per year. ${ }^{14}$ In 2016 net equity issues were

\footnotetext{
12 Michael C. Jensen and Kevin J. Murphy, "Performance Pay and Top Management Incentives," Journal of Political Economy, 98 , 2, 1990: 225-264.

${ }^{13}$ Matt Hopkins and William Lazonick, "The Mismeasure of Mammon: The Uses and Abuses of Executive Pay Data," Institute for New Economic Thinking Working Paper No. 49, at https://www.ineteconomics.org/research/research-papers/themismeasure-of-mammon-uses-and-abuses-of-executive-pay-data

14 In Figure 2, the spike in equity issues for financial corporations in 2009 occurred when some of the largest among them sold stock to the U.S. government in the financial-crisis bailout. The banks that were bailed out had been major repurchasers of their own stock in the years before the financial meltdown. See William Lazonick, "Everyone is paying the price for share buy-
} 
- \$586 billion. Over the past three decades, in aggregate, dividends have tended to increase as a proportion of corporate profits. Yet in 1997 buybacks first surpassed dividends in the U.S. corporate economy and, even with dividends increasing, have far exceeded them in recent stockmarket booms. $^{15}$

Figure 2. Net equity issues, U.S. nonfinancial and financial corporations, 1946-2016

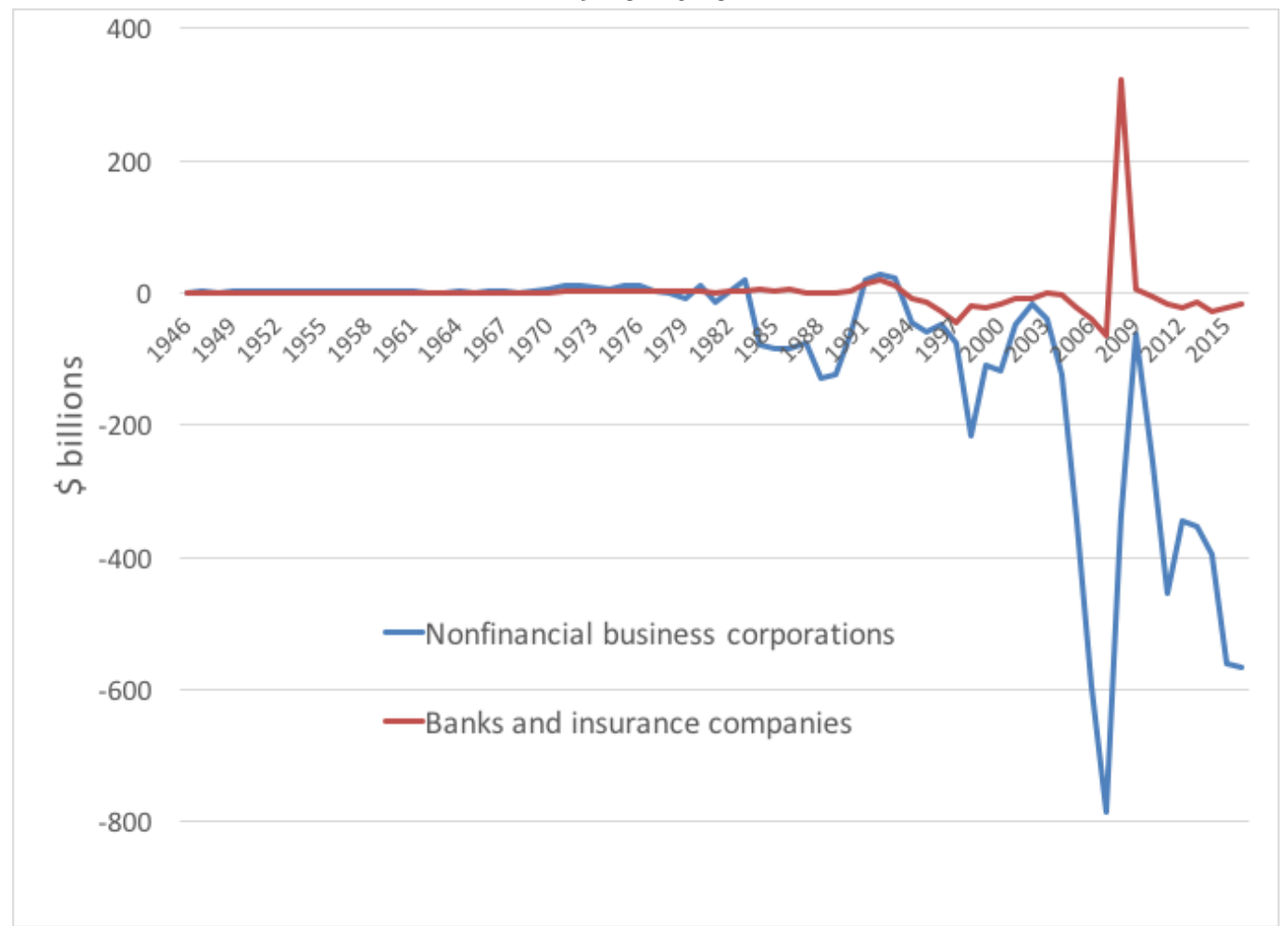

Source: Board of Governors of the Federal Reserve System, Federal Reserve Statistical Release Z.1, "Financial Accounts of the United States: Flow of Funds, Balance Sheets, and Integrated Macroeconomic Accounts," Table F-223: Corporate Equities, March 9, 2017, at https://www.federalreserve.gov/releases/z1/current/

Using the data in Figure 2, the first data column of Table 1 shows the amounts of net equity issues by nonfinancial corporations, decade by decade, from 1946 to 2015, in 2015 dollars. For the first three decades after World War II, net equity issues were moderately positive in the corporate economy as a whole. In the following decades, however, net equity issues became increasingly negative (even after adjusting for inflation). As a gauge of their growing importance in the economy, the second data column of Table 1 shows net equity issues as a proportion of GDP.

backs," Financial Times, September 26, 2008, p. 25, at https://www.ft.com/content/e75440f6-8b0e-11dd-b6340000779fd18c; William Lazonick, "The buyback boondoggle," BusinessWeek, August 24 \& 31, 2009, p. 96.

15 William Lazonick, "Stock Buybacks: From Retain-and-Reinvest to Downsize-and-Distribute," Center for Effective Public Management, Brookings Institution, April 2015, pp. 10-11, at http://www.brookings.edu/research/papers/2015/04/17-stockbuybacks-lazonick; William Lazonick, "The Value-Extracting CEO: How Executive Stock-Based Pay Undermines Investment in Productive Capabilities," Institute for New Economic Thinking Working Paper No. 54, December 4, 2016, at https://www.ineteconomics.org/research/research-papers/the-value-extracting-ceo-how-executive-stock-based-payundermines-investment-in-productive-capabilities. 
Table 1. Net equity issues by non-financial corporations in the U.S. economy, by decade in 2015 dollars, and as a percent of GDP

\begin{tabular}{|l|c|c|}
\hline & $\begin{array}{c}\text { Net equity issues, } \\
\text { U.S. non-financial } \\
\text { corporations } \\
\mathbf{2 0 1 5} \text { \$ billions }\end{array}$ & $\begin{array}{c}\text { Net equity } \\
\text { issues as } \\
\text { \% of GDP }\end{array}$ \\
\hline $\mathbf{1 9 4 6 - 1 9 5 5}$ & 143.2 & 0.56 \\
\hline $\mathbf{1 9 5 6 - 1 9 6 5}$ & 110.9 & 0.30 \\
\hline $\mathbf{1 9 6 6 - 1 9 7 5}$ & 316.0 & 0.58 \\
\hline $\mathbf{1 9 7 6 - 1 9 8 5}$ & -290.9 & -0.40 \\
\hline $\mathbf{1 9 8 6 - 1 9 9 5}$ & $-1,002.5$ & -1.00 \\
\hline $\mathbf{1 9 9 6 - 2 0 0 5}$ & $-1,524.4$ & -1.09 \\
\hline $\mathbf{2 0 0 6 - 2 0 1 5}$ & $-4,466.6$ & -2.65 \\
\hline
\end{tabular}

Sources: Net equity issues data is the same as in Figure 2, adjusted to 2015 U.S. dollars, using the consumer price index in Council of Economic Advisors, Economic Report of the President 2017, January 2017, Table B-10, at http://www.presidency.ucsb.edu/economic reports/2017.pdf.

Over the past three decades, U.S. stock markets, of which the New York Stock Exchange and the National Association of Securities Dealers Automated Quotation (NASDAQ) exchange are by far the most important, have enabled the extraction of trillions of dollars from business corporations in the form of stock buybacks. Of course, some companies do raise funds on the stock market, particularly when they are doing initial public offerings (IPOs). But these amounts tend to be relatively small, swamped overall by stock repurchases, which have been mainly responsible for the hugely negative net equity issues of nonfinancial corporations shown in Figure 1. Moreover, when the most successful startups become major enterprises, often employing tens of thousands of people, they too tend to become major repurchasers of their own shares

I have called this massive flow of cash out of companies "the legalized looting of the U.S. business corporation."16 Most economists, however, adhere to agency theory's contention that, for the sake of economic efficiency, the purpose of the corporation is to "maximize shareholder value," and hence would portray this flow of cash out of companies to the stock market as a "return" of capital to shareholders, who will then reallocate financial resources to their most efficient uses. MSV, however, lacks a theory of the value-creating, or innovative, enterprise and hence can explain neither how these "most efficient uses" come into existence nor, in particular, the role of organizations in creating value in the economy. ${ }^{17}$ Moreover, as already stated, corporations cannot "return" capital to shareholders if those shareholders never provided corporations with capital in the first place. MSV misunderstands the historical role that the stock market has played in the evolution of the U.S. business corporation. ${ }^{18}$ A correct understanding of the evolving functions of the stock market in the U.S. corporate economy supports the hypothesis

\footnotetext{
16 Lazonick, "The Value-Extracting CEO."

17 William Lazonick, Business Organization and the Myth of the Market Economy, Cambridge University Press, 1991; William Lazonick, "The Theory of the Market Economy and the Social Foundations of Innovative Enterprise," Economic and Industrial Democracy, 24, 1, 2003: 9-44; Lazonick, "Innovative Enterprise or Sweatshop Economics?".

18 Lazonick, "The Functions of the Stock Market."
} 
that its current functioning is a prime source of employment instability, income inequity, and slowing productivity. ${ }^{19}$

In this essay, I use innovation theory to provide both a general theoretical critique and a selective empirical critique of agency theory. I originally undertook the writing of this essay as a response to Jesse M. Fried and Charles C. Y. Yang, "Short-Termism and Capital Flows," a working paper that appeared in January $2017 .{ }^{20}$ In this paper, Fried and Wang take aim at arguments that I make concerning the negative impacts of stock buybacks and stock-based executive pay on the performance of U.S. business enterprises in an article, "Profits Without Prosperity," published in Harvard Business Review in August 2014. ${ }^{21}$ As it happened, when the Fried and Wang paper appeared, I was at the final stage of a project with Jang-Sup Shin on the growing imbalance, as a result of increasingly aggressive hedge-fund activism, between those who contribute to the creation of value and those who have the power to extract value in the U.S. economy. ${ }^{22}$ My response to Fried and Wang fits right into our analysis of the origins and impacts of predatory value extraction.

To set the stage for the critique of Fried and Wang, I went back to a book, Pay Without Performance, an agency-theory critique of the stock-based remuneration of senior U.S. corporate executives that Fried had published in 2004 with fellow "law and economics" scholar Lucian Bebchuk. $^{23}$ In this book, Bebchuk and Fried claim that "managerial power," as evidenced in executive remuneration, comes at the expense of the corporation's shareholders. They put forth a number of proposals about how the assertion of power by shareholders can solve this agency problem. In Section 2 of this essay, I argue that Bebchuk and Fried fail to demonstrate that U.S.style stock-based pay undermines "shareholder value," while I contend that, from the perspective of innovation theory, shareholder value is an illegitimate measure of corporate performance.

Over the past decade or so, Bebchuk has emerged as the most influential academic in support of "hedge-fund activism" as a means of confronting managerial power and improving corporate performance. In 2015, Bebchuk published a paper, "The Long-Term Effects of Hedge-Fund Activism," co-authored with Alon Brav and Wei Jiang, in which they purport to demonstrate empirically that the exercise of shareholder power improves corporate operating performance, return on assets, and stock returns over periods of as long as five years. ${ }^{24}$ In Section 3 of this essay, I argue that innovation theory casts serious doubt on the Bebchuk et al. findings because the supposed long-term improvements in corporate performance could very well have resulted from cost-cutting that increased profits at the expense of the labor force rather than from

\footnotetext{
19 Lazonick, "Labor in the Twenty-First Century."

20 Jesse M. Fried and Charles C. K. Wang, "Short-Termism and Capital Flows," Harvard Business School Accounting \& Management Unit Working Paper No. 17-062, January 10, 2017 (revised February 11, 2017), at https://papers.ssrn.com/sol3/papers.cfm?abstract_id=2895161\#\#.

${ }^{21}$ William Lazonick, "Profits Without Prosperity: Stock Buybacks Manipulate the Market and Leave Most Americans Worse Off," Harvard Business Review, September 2014, 46-55.

${ }^{22}$ William Lazonick and Jang-Sup Shin, Rebalancing Value Creation and Value Extraction: How to Deactivate Hedge Funds and Recreate Sustainable Prosperity, Report to the Korea Economic Research Institute, May 31, 2017.

${ }^{23}$ Lucian Bebchuk and Jesse Fried, Pay Without Performance: The Unfulfilled Promise of Executive Compensation, Harvard University Press, 2004.

${ }^{24}$ Lucian A. Bebchuk, Alon Brav, and Wei Jiang, "The Long-Term Effects of Hedge-Fund Activism," Columbia Law Review, 115, 5, 2015: 1085-1155.
} 
productivity gains from the generation of higher quality products at lower unit costs - gains of innovative enterprise that are typically shared with the firm's employees.

Then, in Section 4 of this essay, I turn to a step-by-step critique of Fried and Wang, who take issue with my argument in "Profits Without Prosperity" that massive distributions to shareholders in the forms of dividends and buybacks have come at the expense of investment in innovation and higher wages. Fried and Wang claim that a number of other sources of funds (debt issues, stock issues) and uses of funds (remuneration, R\&D, acquisitions, venture capital) result in innovation and good wages. Invoking both innovation theory and empirical evidence to dissect their arguments, I show that Fried and Wang show nothing of the sort. They make a series of assertions about the economic impacts of financial flows - which they incorrectly call "capital flows" - that lack substance.

I conclude the essay by arguing that, for the sake of analyzing the operation and performance of the economy, innovation theory should replace agency theory. Agency theorists do not address, let alone explain, why since the 1980s, the United States has experienced extreme concentration of income among the richest households and the erosion of middle-class employment opportunities. I contend that the ideology that corporations should be run to "maximize shareholder value" as promulgated by agency theorists has contributed to inferior economic performance. At the same time, I find "short-termism" and "quarterly-capitalism" arguments lacking as explanations for the unproductive, unstable, and inequitable economy that has become characteristic of the United States. Rather, I argue that the critical issue for understanding the role of corporate governance in supporting or undermining economic performance is the relation between value creation and value extraction for those "stakeholders" engaged in the development and utilization of productive capabilities. Innovative enterprise solves the agency problem. By incentivizing and rewarding the real value creators, the innovative enterprise can mobilize the skill, effort, and finance that, by generating high-quality, low-cost products, can improve the performance of the economy-defined in terms of stable and equitable economic growth.

\section{Agency Theory and the Persistence of Managerial Power}

From the perspective of agency theory, one would have thought that coming into the twenty-first century the agency problem would have been solved. In the boom period 1997-2000, with profits soaring, 410 S\&P 500 companies distributed 45 percent of net income as buybacks and another 34 percent as dividends. In 2000, the mean total remuneration of the 500 highest-paid U.S. executives was $\$ 32.3$ million, of which about 80 percent was realized gains from exercising stock options and another five percent was from the estimated value of stock awards. The incentives of top executives were assumed to be aligned with shareholders, and these executives were distributing massive sums of cash flow to them. MSV ideology prevailed, virtually unchallenged, in corporate boardrooms and business schools. ${ }^{25}$ During the Internet boom of 1997-2000, the application of agency theory and the prosperity of the U.S. economy seemed to go hand in hand.

But in 2001-2002 the boom of the late 1990s turned to bust, and the Enron scandal, which broke in late 2001, followed by the Worldcom bankruptcy the following year, left self-dealing

${ }^{25}$ Lazonick and O'Sullivan, "Maximizing Shareholder Value." 
corporate executives open to blame. In the wake of the bursting of the Internet bubble, the excesses of the late 1990s brought a critique of overvalued equities even from Michael Jensen, the Harvard Business School professor who throughout the 1980s and 1990s had been the most prominent MSV academic arguing for the need to increase the stock-based pay of top executives to align their interests with those of shareholders. ${ }^{26}$ Yet a 2002 article, "Just Say No to Wall Street: Putting a Stop to the Earnings Game," which Jensen co-authored with consultant executive Joseph Fuller, exhorted CEOs to resist the demands of Wall Street financial analysts for companies to report higher earnings to justify higher stock prices. ${ }^{27}$ They blamed corporate executives for collaborating with Wall Street in the overvaluation of their companies' shares, with a resultant misallocation of resources. As one of their two examples (the other being Enron), Fuller and Jensen found fault with the telecommunications-equipment company Nortel Networks for spending over $\$ 32$ billion in 1997-2001 on acquisitions, purchased mainly with overvalued stock instead of cash, that subsequently had to be written off or shut down. Encouraging Nortel's top management in this behavior, Fuller and Jensen recognized, was "the incentive to maintain the value of managerial and employee stock options.",28

For agency theorists, therefore, the experience of the Internet boom and bust suggested that, notwithstanding supposedly shareholder-friendly stock-based pay, corporate executives retained too much power. Two agency theorists, Lucian Bebchuk and Jesse Fried, trained in law and economics, put forward the "managerial power" thesis in a 2004 book, Pay Without Performance: The Unfulfilled Promise of Executive Compensation. ${ }^{29}$ Their argument in the book is straightforward:

a) Senior corporate executives control the appointment of boards of directors, placing limits on the power of shareholders to exert influence on managers to ensure that these executives refrain from "empire building" (a phrase that they use repeatedly) rather than serving the interests of shareholders.

b) Senior executives use this power to get the board to approve high levels of senior-executive pay, generous benefits, and low- or no-interest loans, all at the expense of shareholders.

c) Of particular importance in "decoupling" executive pay from the interests of shareholders is stock-based compensation in the form of stock options, which gives executives windfall rewards for stock-market booms and is open to abuse through practices such as the repricing of stock options that are under water.

Bebchuk and Fried call for improvements in i) executive compensation, through the indexing of stock options to the stock market so that the gains from them reflect actual managerial contributions to shareholder value rather than rewards from and reactions to more general stockmarket volatility, and ii) corporate governance, so that boards serve the interests of the

\footnotetext{
${ }^{26}$ Jensen and Murphy, "Performance Pay."

27 Joseph Fuller and Michael C. Jensen, "Just Say No to Wall Street: Putting a Stop to the Earnings Game," Journal of Applied Corporate Finance, 14, 4, 2002: 41-46.

28 Ibid., p. 44. For the case of Nortel, see Marie Carpenter, William Lazonick, and Mary O'Sullivan, "The Stock Market and Innovative Capability in the New Economy: The Optical Networking Industry," Industrial and Corporate Change, 12, 5, 2003: 963-1034. See also William Lazonick and Edward March, "The Rise and Demise of Lucent Technologies," Journal of Strategic Management Education, 7, 4, 2011.

${ }^{29}$ Bebchuk and Fried, Pay Without Performance.
} 
corporation's shareholders rather than managers, who are assumed to be the shareholders' agents.

Bebchuk and Fried conclude with a call to arms:

The power of the board, and its insulation from shareholders, is [sic] often viewed as an inevitable corollary of the modern corporation's widely dispersed ownership. But this power is partly due to the legal rules that insulate management from shareholder intervention. Changing these rules would reduce the extent to which boards can stray from shareholder interests and would much improve corporate performance. ${ }^{30}$

There is much truth in the Bebchuk and Fried arguments about managers' power and its translation into their excessively high levels of remuneration. There are, however, enormous gaps in their analysis. They provide no discussion of how the exercise of managerial power and "excessive" executive pay actually inflict losses on shareholders. They fail to explain why, if executives reap windfall gains from stock-market booms, shareholders do not gain from these booms as well. And they do not consider the powerful incentives created for executives who are given repriced stock options when the stock market is down to pursue strategies to boost the company's stock prices, thus benefiting shareholders.

A particularly glaring omission in their analysis is the critical issue of distributions to shareholders in the form of dividends. They do not discuss dividend-payout policy at all — the term "dividend" is never mentioned in their book! Whether executives should be paying more in dividends and retaining less in profits in line with MSV is a fundamental question for assessing how managerial resource-allocation decisions affect shareholders' interests.

Corporations also distribute cash to shareholders in the form of stock buybacks. ${ }^{31}$ Bebchuk and Fried's only mention of stock repurchases is in an endnote. Citing previous research by Fried on insider trading around stock repurchases, they argue that managers may use "material" inside information, "without much fear of detection" by the SEC, when trading in company stock. ${ }^{32}$ Some pages later, Bebchuk and Fried argue: "Executives who are free to unload shares or options may have incentives to jack up short-term stock prices by running the firm in a way that improves short-term results at the expense of long-term value." 33 They go on:

A growing body of empirical work supports the view that managers' freedom to unload options and shares has provided them with undesirable incentives. Several studies find evidence that managers whose compensation is more directly tied to share prices are more likely to manipulate earnings. The empirical evidence also

\footnotetext{
${ }^{30}$ Ibid., p. 216.

${ }^{31}$ Lazonick, "Profits Without Prosperity"; Lazonick, "Stock Buybacks."

32 Bebchuk and Fried, Pay Without Performance, p. 179 and p. 251, n. 18. They cite Jesse M. Fried, "Reducing the Profitability of Corporate Insider Trading Through Pretrading Disclosure," Southern California Law Review, 71, 2, 1998: 302-392; Jesse M. Fried, "Insider Signaling and Insider Trading with Repurchase Tender Offers," University of Chicago Law Review, 67, 2, 2000: 421-477; Jesse M. Fried, “Open Market Repurchases: Signaling or Managerial Opportunism," Theoretical Inquiries in Law, 2, 2, 2001: 865-84.

${ }^{33}$ Bebchuk and Fried, Pay Without Performance, p. 184,
} 
suggests that managers engage in earnings manipulation and fraud in order to unload shares at a higher price.

There is, however, no explicit mention of buybacks as one of the methods that executives might use to "jack up short-term stock prices." Hence Bebchuk fail to raise, let alone answer, the most salient questions concerning the role of stock buybacks in the exercise of managerial power. Should shareholders have an interest in open-market stock repurchases done under SEC Rule 10b-18, which gives executives and the board an expansive "safe harbor" against charges of stock-price manipulation? ${ }^{34}$ Given that only insiders know the specific days on which openmarket repurchases are being done, would it not be expected that buybacks would be of most benefit to senior executives who have material inside information that can be used to time the exercise of their stock options to enhance the realized gains from their stock-based pay? ${ }^{35}$

A central critique of executive pay that Bebchuk and Fried put forward in Pay Without Performance is that the stock-based pay of senior executives benefits from movements in stock prices unrelated to a firm's performance but, rather, reflecting general stock-price fluctuations. They observe that senior executives benefit from general stock-market volatility, and they argue for indexing executive stock options to eliminate this "pay without performance." But, given general stock-market volatility, what drives a company's stock price? My research finds that a company's stock price can be driven by innovation, speculation, and manipulation. ${ }^{36}$ If we want stock-based executive pay to be linked to a company's performance, we should structure it to reflect stock-price movements that result from innovation rather than movements that result from speculation or manipulation.

The formulation of policy to regulate executive pay would require a theory of innovation as a driver of stock prices, a perspective which is absent from the Bebchuk-Fried analysis, as from agency theory more generally. While Bebchuk and Fried contend that executives "jack up shortterm stock prices by running the firm in a way that improves short-term results at the expense of long-term value," they put forward no theoretical perspective on what types of actions managers should take to generate "long-term value." Drawing on The Theory of Innovative Enterprise, we ask what roles strategic control, organizational integration, and financial commitment play in generating the high-quality, low-cost products that are the source of "long-term value." Bebchuk and Fried have absolutely nothing to say about organizational integration and financial commitment.

Their sole argument, which relates to strategic control, is that public shareholders should exert their power to rein in self-dealing managers. But they do not ask how shareholders have the ability, even if they have the incentive, to correct the problem of executives as value-extracting insiders. They do not explain how public shareholders, who merely buy and sell shares on the stock market, could and would make contributions to "long-term value" if they could exercise

\footnotetext{
${ }^{34}$ Lazonick, "Stock Buybacks." Rule 10b-18 grants a safe harbor against charges of manipulation if, along with other stipulations, the volume of shares repurchased on any one day does not exceed 25 percent of the average daily trading volume of the shares over the previous four weeks.

${ }^{35}$ The SEC does not require companies to announce the dates on which open-market purchases are being done, although highlevel insiders obviously have this information. Also, under Rule 10b-18, a company must do all its open-market repurchases on any given day through one broker, creating a possible source of inside information about that company's buyback activity.

${ }^{36}$ Lazonick, "The Value-Extracting CEO."
} 
more power over managers. They look to activist shareholders to counter managerial power, but they provide scant analysis of what these activist shareholders are able or willing to do as "longterm investors."

\section{The Purported Efficiencies of Hedge-Fund Activism}

This lack of an analysis of the sources of "long-term value" has not stopped Bebchuk from advocating the methods by which it should be achieved. Building on the "managerial power" argument, Bebchuk has emerged over the past decade as the leading academic proponent of "hedge-fund activism" as a prime source of superior economic performance. In a paper "The Long-Term Effects of Hedge Fund Activism," co-authored with Alon Brav and Wei Jiang, Bebchuk uses a dataset that purports to provide evidence that, over the five-year period after a hedge-fund intervention in a company, operating profits and stock prices tended to increase. ${ }^{37}$ As Bebchuk et al. summarize their findings in a blog post on the website of the Harvard Law School Forum on Corporate Governance and Financial Regulation (hereafter "HLS Forum"):

Our study uses a dataset consisting of the full universe of approximately 2,000 interventions by activist hedge funds during the period 1994-2007. We identify for each activist effort the month (the intervention month) in which the activist initiative was first publicly disclosed (usually through the filing of a Schedule 13D). Using the data on operating performance and stock returns of public companies during the period 1991-2012, we track the operating performance and stock returns for companies during a long period-five years-following the intervention month. We also examine the three-year period that precedes activist interventions and that follows activists' departure.

Starting with operating performance, we find that operating performance improves following activist interventions and there is no evidence that the improved performance comes at the expense of performance later on. During the third, fourth, and fifth year following the start of an activist intervention, operating performance tends to be better, not worse, than during the preintervention period. Thus, during the long, five-year time window that we examine, the declines in operating performance asserted by supporters of the myopic activism claim are not found in the data. We also find that activists tend to target companies that are underperforming relative to industry peers at the time of the intervention, not well-performing ones.

We then turn to stock returns following the initial stock price spike that is wellknown to accompany activist interventions. We first find that, consistent with the results obtained with respect to pre-intervention operating performance, targets of activists have negative abnormal returns during the three years preceding the intervention. We then proceed to examine whether, as supporters of the myopic activism claim to believe, the initial stock price reflects inefficient market pricing

\footnotetext{
${ }^{37}$ Bebchuk, et al., "The Long-Term Effects of Hedge-Fund Activism."
} 
that fails to reflect the long-term costs of the activist intervention and is thus followed by stock return underperformance in the long term. ${ }^{38}$

The most vocal critic of Bebchuk et al. has been the lawyer Martin Lipton of the law firm Wachtell, Lipton, Rosen \& Katz. Lipton has spent his career defending incumbent executives against corporate raiders. In the $1980 \mathrm{~s}$, as a managerial defense against takeover bids, Lipton designed the "poison pill," a legal arrangement that sets in motion stock issues that dilute the shareholding and voting power of the corporate raider. In February 2013, about six months before the initial release of the Bebchuk et al. paper, in an HLS Forum blog post, "Bite the Apple; Poison the Apple; Paralyze the Economy; Wreck the Economy," Lipton had criticized in no uncertain terms the attack on Apple led by hedge-fund activist David Einhorn that was taking place at the time. ${ }^{39}$

As Lipton led off the post: "The activist-hedge-fund attack on Apple - in which one of the most successful, long-term-visionary companies of all time is being told by a money manager that Apple is doing things all wrong and should focus on short-term return of cash-is a clarion call for effective action to deal with the misuse of shareholder power." Lipton took specific aim at Bebchuk as an agent of the hedge-fund activists:

These self-seeking activists are aided and abetted by Harvard Law School Professor Lucian Bebchuk who leads a cohort of academics who have embraced the concept of "shareholder democracy" and close their eyes to the real-world effect of shareholder power, harnessed to activists seeking a quick profit, on a targeted company and the company's employees and other stakeholders.

Given that Bebchuk had announced that that he was conducting (in Lipton's words) "empirical studies to prove his thesis that shareholder demand for short-term performance enforced by activist hedge funds is good for the economy," Lipton countered that

if Professor Bebchuk is truly interested in meaningful research to determine the impact of an activist attack (and the fear of an activist attack) on a company, he must first put forth a persuasive (or even just coherent) theory as to why the judgments as to corporate strategy and operations of short-term-focused professional money managers should take precedence over the judgments of directors and executives charged with maximizing the long-term success of business enterprises.

Lipton is correct to demand that Bebchuk articulate a plausible theory about why the judgments of financial outsiders concerning business strategy should prevail over those of managerial

\footnotetext{
38 Ibid.

39 Lipton's blog post is at https://corpgov.law.harvard.edu/2013/02/26/bite-the-apple-poison-the-apple-paralyze-the-companywreck-the-economy/. On Apple's business model and the quest for "shareholder value," see William Lazonick, Mariana Mazzucato, and Öner Tulum, "Apple's Changing Business Model: What Should the World's Richest Company Do With All Those Profits?" Accounting Forum, 37, 4, 2013: 249-267; Lazonick, "Numbers show Apple shareholders have already gotten plenty"; William Lazonick, Matt Hopkins, and Ken Jacobson, "What we learn about inequality from Carl Icahn's \$2 billion 'no brainer,'” Institute for New Economic Thinking Ideas \& Papers, June 6, 2016, at https://ineteconomics.org/ideaspapers/blog/what-we-learn-about-inequality-from-carl-icahns-2-billion-apple-no-brainer
} 
insiders. The problem, however, is that since the 1980s senior executives of major U.S. corporations, with their stock-based pay, have become "value-extracting insiders," 40 who, to their own benefit, have been participating in the legalized looting of the business corporation. I argue that, on an ever-increasing scale, senior executives have become predatory value extractors who secure gains from the corporation that are far in excess of their contributions to the valuecreation process. Hence, I reject Lipton's assumption that, after a quarter century of embracing MSV ideology, incumbent directors and executives of U.S. business corporations have the incentives, or even the abilities, to make resource-allocation decisions consonant with "the longterm success of the business enterprises" over which they exercise strategic control. One cannot begin to analyze the long-term success of the business enterprise unless one possesses a theory of the value-creating firm that, through the interactions of strategic control, organizational integration, and financial commitment, generates high-quality, low-cost goods and services that are competitive on product markets.

As manifested in distributions to shareholders, buybacks in particular, and by the explosion of stock-based executive pay, the financialization of the U.S. business corporation took root in the late 1980s and 1990s, preceding the rise of the new corporate predators called "hedge-fund activists." Both senior executives as value-extracting insiders and activist shareholders as valueextracting outsiders place personal gain ahead of the investments in the value-creating capabilities of the business enterprise that are necessary for "long-term success." From this perspective, the distinction between "short term" and "long term" misses the point: The real problem is a growing imbalance of power between those who make contributions to value creation and those who reap income through value extraction.

At major business enterprises that, typically over decades, have accumulated value-creating capabilities, predatory value extraction can take place over many years, and in some cases over one or more decades, before those accumulated capabilities are run into the ground. For the largest companies that have been subjected to predatory value extraction-Exxon Mobil, IBM, Microsoft, Cisco, Hewlett-Packard, Pfizer, Merck, and many more - there is a middle stage between "retain-and-reinvest," during which value-creating capabilities are accumulated, and "downsize-and-distribute," during which the value generated by the previously-created productive capabilities is extracted. I call this middle stage "dominate-and-distribute," a period that may stretch out over the "long term," during which a company continues to generate substantial revenues and profits from product segments that it came to dominate in its "retainand-reinvest" stage.

For a major company, "dominate-and-distribute" can last for a decade or two, but eventually the domination of those product segments will decline. Without successful investments in innovative products on a scale that can sustain a large company into the future, it will enter into the "downsize-and-distribute" stage, with, under the MSV-oriented institutional framework that prevails in the United States, households as workers and taxpayers bearing the burden of "downsize" while predatory value extractors - senior executives, hedge-fund managers, and Wall Street bankers - reap the rewards of "distribute."

\footnotetext{
${ }^{40}$ Lazonick, "The Value-Extracting CEO"; Lazonick and Shin, Rebalancing Value Creation and Value Extraction.
} 
Missing from the Bebchuk-Lipton debate over whether it should be public shareholders or corporate managers exercising strategic control over the allocation of corporate resources is any acknowledgment of the role of households as workers and taxpayers as contributors to the process of value creation. At the same time, I find the short-termism and quarterly-capitalism arguments lacking as explanations for the unproductive, unstable, and inequitable economy that has become characteristic of the United States. Rather the extent to which the increasing financialization of the corporation comes at the expense of these stakeholders is the result of the processes of predatory value extraction. Lipton in effect argues that Bebchuk lacks a theory of who should control corporate resource allocation, i.e., a theory of strategic control. But what agency theory most conspicuously lacks is a theory of the value-creating enterprise, which includes not only strategic control but also organizational integration and financial commitment as social conditions that enable a company to generate high-quality, low-cost products.

In suffering from this theoretical weakness, Bebchuk is by no means unique. As a $\mathrm{PhD}$ economist (as well as a Doctor of Law), Bebchuk was nurtured on the neoclassical theory that the unproductive firm is the foundation of the most efficient economy. ${ }^{41} \mathrm{He}$ propounds a particular version of agency theory that argues that for the sake of superior economic performance the business corporation should maximize shareholder value. Bebchuk's work builds on that of Michael Jensen, the foremost proponent of MSV in the 1980s and 1990s. But, in aiding and abetting hedge-fund activism in the twenty-first century, Bebchuk takes the legalized looting of the business corporation even further.

Jensenite agency theory exhorted corporate executives to increase the distribution of cash flow from companies to shareholders in order to allocate resources away from allegedly inefficient companies to purportedly efficient companies. Jensen argued that corporate executives should be incentivized by stock-based pay to "disgorge" the "free" cash flow. The use of the term "disgorge" implies that managers are seeking to obstruct the distribution of cash that rightfully belongs to shareholders. In fact, a major portion of the so-called "free" cash flow represents value created by the skills and efforts of employees with the support of tax dollars spent through government agencies to provide companies with infrastructure and knowledge. In Pay Without Performance, Bebchuk and Fried in effect argue - although, as we have seen, in an inchoate manner - that, from the perspective of the early 2000s, stock-based incentives for senior corporate executives have not worked to benefit the shareholders, for whom, in their view, the business enterprise should be run. In doing so, they set the stage for advocating that shareholder "activists" intervene directly in companies to "create value" for all shareholders.

In the article "The Long-term Effects of Hedge-Fund Activism," Bebchuk et al. adduce empirical evidence to respond to critics like Lipton, jurist Leo Strine, legal scholar William Bratton, economists Michael Wachter and (in the UK) John Kay, retired executive Bill George, journalist Justin Fox, and business academic Jay Lorsch, ${ }^{42}$ who say that hedge-fund activists are reaping rewards in the "short term" at the expense of the long-term performance of the firm. Bebchuk et al. state:

\footnotetext{
${ }^{41}$ Lazonick, "Innovative Enterprise or Sweatshop Economics?"

42 Bebchuk et al. "The Long-Term Effects," p. 1094 (note 22).
} 
Even assuming that capital markets are informationally inefficient and activists have short investment horizons, the claim that activist interventions are detrimental to the long-term interests of shareholders and companies does not necessarily follow as a matter of theory. The claim is thus a factual proposition that can be empirically tested. However, those advancing the myopic-activists claim have thus far failed to back their claims with large-sample empirical evidence, relying instead on their (or others') impressions and experience. ${ }^{43}$

There are, however, fundamental flaws in the Bebchuk, Brav, and Jiang analysis of "largesample empirical evidence" (as described by them, above). The first major problem is that, over the course of five years from the date of the 13D filings, almost half of the firms disappear from the Compustat database that Bebchuk et al. use to calculate Tobin's Q (the measure of the firm's market value to book value) and return on assets (ROA).$^{44}$ In the case of Q, the number of firms that remain in Compustat declines from 1,611 in the year of the 13D filing to 831 five years later, and in the case of ROA, the decline is from 1,584 to 815 . These firms disappear because they are delisted from the stock market. It would require research on each case to know why the delisting occurred; disappearance from Compustat may have been caused by a firm's going out of business, its failure to maintain the minimum listing requirements of the stock market, or its having been acquired. Once these firms have disappeared, Bebchuk et al. cannot calculate $\mathrm{Q}$ or ROA for them.

Bebchuk at al. assert that most of the disappearances from Compustat result from acquisitions, but this conclusion seems to be based on surmise. They also state that "when we compare the target firms to peer companies matched by size and performance, we find that the matched firms also have a high attrition rate of $42 \%$ within five years; most of the disappearances from Compustat are again due to acquisitions. ${ }^{.45}$

What we want to know, however, is the extent to which predatory value extraction is the underlying cause of the delisting of firms, even if the proximate cause was firm liquidation, listing-requirement insufficiency, or acquisition. Furthermore, the fact that the firms in the Bebchuk et al. control group were not the subjects of a 13D filing does not, on that basis, necessarily mean they were immune to predatory value extraction. Given that predatory value extraction is perpetrated by both senior executives as insiders and activist shareholders as outsiders, excessive distributions to shareholders could have triggered any of these outcomes among the control group. Moreover, even without a 13D filing, value-extracting outsiders can pressure value-extracting insiders to intensify "downsize-and-distribute." The Bebchuk et al. analysis provides no information on why the firms disappeared from the database for either the $13 \mathrm{D}$ group or the control group.

As for the firms that remained in the dataset after the 13D filings, the Bebchuk et al. analysis tells us nothing about whether an increase in Q, ROA, or stock prices, even one coming as long as five years after a 13D filing, reflects investments in value creation or resource-allocation

\footnotetext{
${ }^{43}$ Ibid., pp. 1088-1089. On the theory that shareholder activism creates long-term value, they cite Lucian A. Bebchuk, "The Myth that Insulating Serves Long-Term Value," Columbia Law Review, 113, 2013: 1637-1694.

${ }^{44}$ Bebchuk et al. "The Long-Term Effects," p. 1104.

${ }^{45}$ Ibid. Again it is not clear that the authors carried out research to document that acquisitions account for most of the disappearances, or whether this statement is merely an assertion.
} 
decisions for the sake of value extraction. As a rule, agency theorists view corporate investments in value-creating projects as wasteful "empire-building" expenditures ex ante. But they are only too ready to assume that the profits from successful value-creating projects belong to shareholders, including corporate raiders, ex post. There is virtually no evidence that hedge-fund activists intervene in companies to promote investments in innovative products that may, or may not, pay off in the future. There are mountains of evidence, if only by their own accounts, that hedge-fund activists intervene in companies to put a stop to the allocation of corporate resources to investments in value-creating projects. Instead, they insist that the target company sell off assets and slash "costs"-which often means layoffs and wage cuts inflicted on the very employees whose skills and efforts helped to create the value that shareholder outsiders, with the assistance of executive insiders, are determined to extract for their own personal benefit. ${ }^{46}$

In the process, these outsider interventions may very well undermine the value-creating investments that a firm has undertaken. Some three to five years after the announced intervention (the 13D filing), measures of performance such as Q, ROA, and stock price may show improvement, but that improvement may reflect the fact that the hedge-fund activists have targeted a company with an accumulation of revenue-generating capability that, from their MSV perspective, is ripe for being hollowed out. Indeed, these are precisely the types of targets over which predatory value extractors salivate as they use the power of purchased shareholdings to (as they put it) "create" value for themselves.

Increasingly since the 1980s, the real value creators - workers and taxpayers-have been paying the price for predatory value extraction run wild. Bebchuk et al. provide no explanation for the extreme concentration of income among the richest households and the erosion of middle-class employment opportunities in the United States over the past three decades. We have amassed considerable research that attributes these macroeconomic outcomes to the growing imbalance between value creation and value extraction in major U.S. business corporations, under the influence of MSV. ${ }^{47}$ With the transformation of corporate resource allocation from a regime of retain-and-reinvest to one of downsize-and-distribute, senior corporate executives and powerful activist shareholders have gained at the expense of increasing proportions of the U.S. labor force, who find that middle-class employment opportunities have disappeared.

\section{Financial Flows and Innovative Enterprise}

In my Harvard Business Review article "Profits Without Prosperity: Stock Buybacks Manipulate the Market and Leave Most Americans Worse Off," I argue that stock-based pay incentivizes corporate executives to do massive stock repurchases for their own benefit and at the expense of U.S. households as workers and taxpayers. By the beginning of the 1990s, U.S. corporate executives had almost completely embraced MSV ideology. Since the 1980s, corporate raiders, now known as hedge-fund activists, have also become profoundly involved in this process of predatory value extraction. In the 1980s, one often heard the term "hostile" in discussions of the attacks on a corporation by a raider such as Carl Icahn. One rarely hears that term now because

\footnotetext{
${ }^{46}$ Lazonick and Shin, Rebalancing Value Creation and Value Extraction, ch. 6.

${ }^{47}$ Much of this research can be found on the websites of the Institute for New Economic Thinking (https://www.ineteconomics.org/research/experts/wlazonick) and the Academic-Industry Research Network (www.theAIRnet.org)
} 
senior executives and activist shareholders have found common cause in predatory value extraction. The rise of the hedge-fund activists has made a bad situation - unstable employment, inequitable income, and sagging productivity — far worse.

I have been a critic of agency theory since the late 1980s, when I witnessed first-hand its rise to dominance as the ideology of corporate governance at Harvard Business School (HBS). After an HBS seminar in 1992 in which I presented a paper, "Controlling the Market for Corporate Control," that critiqued agency theory from a historical perspective, ${ }^{48}$ the paper's discussant, HBS Professor Michael C. Jensen, issued an informal but effective ban on my being invited back to HBS. ${ }^{49}$ Beyond Jensen's activist intervention, however, agency theorists have been inclined to ignore both my research on the innovative enterprise and my critiques of their point of view.

Recently, however, Jesse Fried and Charles Wang published a working paper, "Short-Termism and Capital Flows," 50 that critiques one of my central propositions in "Profits Without Prosperity." We have already met Fried as the co-author with Bebchuk of the 2004 book Pay Without Performance, which I reviewed above. Like Bebchuk, Fried is a professor at Harvard Law School, while Wang, a recent $\mathrm{PhD}$ in economics from Stanford University, is a junior faculty member at HBS. Fried and Wang contend that, contrary to Lazonick, the fact that distributions to shareholders in the form of dividends and buybacks absorb almost all of the net income of companies in the S\&P 500 Index does not undermine companies' investment in innovation and provision of good wages to their workers. There are, however, glaring omissions, factual inaccuracies, and logical inconsistencies in their arguments.

Fried and Wang agree that, among S\&P 500 companies, buybacks and dividends absorb more than 90 percent of net income. But they argue that because S\&P 500 companies issue debt and because they raise money from stock issues, they have plenty of capital to finance investment in innovation and to pay good wages. They also observe that money that companies spend on R\&D counts as an expense and is deducted before arriving at net income - so that, even if the payout ratio is high, there exist $R \& D$ expenditures that can fund investment in innovation and result in good wages. Furthermore, they note, companies issue stock to provide income to employees via stock-based pay and use it as a currency to do acquisitions. In addition, they argue that distributions to shareholders may be used to fund venture-backed startups. These sources and uses of funds, they assert, result in innovation and good wages.

With all these sources and uses of funds present within both companies and the economic system as a whole, Fried and Wang contend, payout ratios of cash dividends and stock buybacks to net income of 90 percent or more are not detrimental to achieving innovation and good wages. Yet, they say: "Academics, corporate lawyers, asset managers, and politicians point to such shareholder-payout figures as compelling evidence that 'short-termism' and 'quarterly

\footnotetext{
${ }^{48}$ William Lazonick, "Controlling the Market for Corporate Control: The Historical Significance of Managerial Capitalism," Industrial and Corporate Change, 1, 3, 1992: 445-488.

${ }^{49}$ The story is told in Duff McDonald, "Harvard Business School and the propagation of immoral profit strategies," Newsweek, April 14, 2017, at http://www.newsweek.com/2017/04/14/harvard-business-school-financial-crisis-economics-578378.html; Duff McDonald, The Golden Passport: Harvard Business School, The Limits of Capitalism, and the Failure of the MBA Elite, HarperCollins, 2017, pp. 376-378.

${ }^{50}$ Fried and Wang, "Short-Termism and Capital Flows."
} 
capitalism' are impairing firms' ability to invest, innovate, and provide good wages."51 At the beginning of their paper, they write: "Much of the focus on shareholder payouts is due to the work of economist William Lazonick, who has repeatedly and forcefully argued that these shareholder payouts - and buybacks in particular - impair firms' ability to invest, innovate, and provide good wages." They then quote a passage from my $H B R$ article, "Profits Without Prosperity," in which I say that high payout ratios leave "very little for investments in productive capabilities or higher incomes for employees."

Note that in their paper Fried and Wang document aggregate capital-or, more correctly, financial-flows, but they do not provide an iota of empirical evidence of the results they claim from these flows: innovation and good wages. The overriding reason for this omission is that, like agency theorists in general, they lack a theory of the value-creating enterprise, including a theory of the distribution of the gains from value-creation among participants in the valuecreation process. Hence, Fried and Wang are unable to test the very hypotheses that they purport to refute. As for evidence that I have to offer on this subject, save for citing the well-known article "Maximizing Shareholder Value: A New Ideology for Corporate Governance" that I published in 2000 with Mary O'Sullivan, Fried and Wang make no reference to the substantial body of theoretical and empirical research that underpins my arguments in "Profits Without Prosperity."

Drawing on this body of research, my critique of Fried and Wang centers on two broad points:

* Cash flows that represent certain SOURCES of funds-Fried and Wang discuss debt issues and stock issues - tell us nothing about the USES of funds.

* Cash flows that represent certain USES of funds-Fried and Wang discuss stock-based pay, $\mathrm{R} \& \mathrm{D}$, acquisitions, and venture capital-tell us nothing about the PERFORMANCE of funds: that is, whether or not these uses of funds result in innovation and higher wages.

Fried and Wang assume that the particular source of funds-equity or debt - is immaterial to corporate investment in productive capabilities. In this, they echo the Modigliani-Miller theorem of the irrelevancy of corporate capital structure, ${ }^{52}$ a dominant, yet naïve, view of corporate finance. The Modigliani-Miller theorem makes no sense from the perspective of strategic control over the allocation of resources and the need for financial commitment to implement an innovative investment strategy, two social conditions that are central to The Theory of Innovative Enterprise.

The use of debt exposes the firm to financial fragility and even bankruptcy, while the use of equity does not. Those who exercise strategic control over the allocation of corporate resources need to pay close attention to the company's capital structure and its relation to corporate cash flow. ${ }^{53}$ In an innovative enterprise, committed finance is critical to fund not solely, or even

\footnotetext{
51 Ibid., Abstract.

${ }^{52}$ Franco Modigliani and Merton Miller, "The Cost of Capital, Corporation Finance and the Theory of Investment," American Economic Review. 48, 3, 1958: 261-297.

53 This sensible view of corporate finance prevailed in U.S. business schools before the 1980 s when, via agency theory, the absurdities of neoclassical economic theory invaded that academic territory. See, for example, Gordon Donaldson, Corporate
} 
primarily, physical capital expenditures, but also organizational learning, which is an uncertain, collective, and cumulative process. Financial commitment is required to sustain this learning process from the time at which investments in productive capabilities are made until the time that the generation of high-quality, low-cost products that can compete on markets provide profits to the firm.

Innovation secures financial commitment from equity finance, of which retained earnings are a critical foundation, leveraged if need be by debt. The use of debt as a replacement for equity to fund the innovation process would require that a company take on high levels of debt without the flow of revenues or the accumulated equity being available to service that debt. It is a recipe for financial disaster that any value-creating enterprise would seek to avoid.

More generally, the Fried and Wang arguments reflect the neoclassical notion that all that matters to economic performance is the uninhibited movement of finance through the economic system to its most efficient uses. But lacking a theory of innovative enterprise, the neoclassical economist is bereft of an explanation of the value-creating processes that permit those most efficient uses to come into existence. Indeed, it is the free-market economist's notion that financial mobility trumps financial commitment in the determination of economic outcomes that often gives rise to the charges of "short-termism" and "quarterly capitalism" that Fried and Wang seek to dismiss. ${ }^{54}$

That having been said, I also, as already indicated, find the short-termism and quarterlycapitalism arguments lacking as explanations for an unproductive, unstable, and inequitable economy. ${ }^{55}$ Rather, I argue that the critical issue for understanding the role of corporate governance in supporting or undermining the achievement of stable and equitable economic growth is the relation between value creation and value extraction for those "stakeholders" engaged in the development and utilization of the company's productive capabilities.

One needs a theory of innovative enterprise to analyze whether cash flows result in innovationthat is to say, value creation - and higher wages - that is to say, value extraction that accurately reflects the contributions of a company's workers to value creation. Armed with The Theory of Innovative Enterprise, we can focus on the social conditions-strategic control, organizational integration, and financial commitment - that result in innovation and higher wages. And we can then see the logic, consistent with the facts, of why massive stock buybacks tend to undermine the social conditions of innovative enterprise. Agency theory is rooted in an ideology that justifies value extraction - an inequitable form of which is designated by the term "maximizing shareholder value" - while lacking a theory of value creation, and as such serves to legitimize growing income inequality and the erosion of middle-class employment opportunities. Both have

Debt Capacity: A Study of Corporate Debt Policy and the Determination of Corporate Debt Capacity, Graduate School of Business Administration, Harvard University, 1961 (republished by Beard Books, 2000).

54 In the same vein, see Steven N. Kaplan. "Are U.S. Companies Too Short-Term Oriented? Some Thoughts," National Bureau of Economic Research Working Paper 23464, June 2017.

${ }^{55}$ William Lazonick, "Creating and Extracting Value: Corporate Investment Behavior and American Economic Performance," in Michael A. Bernstein and David E. Adler, eds., Understanding American Economic Decline, Cambridge University Press, 1994: 79-113; Lazonick and O'Sullivan, "Maximizing Shareholder Value"; William Lazonick, "Clinton's proposals on stock buybacks don't go far enough," Harvard Business Review, August 11, 2015, at https://hbr.org/2015/08/clintons-proposals-on-stockbuybacks-dont-go-far-enough. 
been widely recognized "performance" outcomes of the U.S. economy since the 1980s —albeit not the outcomes that most of us want. The allocation of corporate resources to stock buybacks has been central to the generation of these outcomes, with damaging impacts on innovation and income distribution.

In this critique, I summarize the factual problems and logical inconsistencies with the Fried and Wang arguments concerning a) debt issues, b) stock issues, c) stock-based pay, d) R\&D, e) acquisitions, and f) venture capital. One cannot assume that the sources of funds (debt issues and stock issues) and uses of funds (stock-based pay, R\&D, acquisitions, and venture capital) that Fried and Wang identify as resulting in "investment, innovation, and good wages" have in fact had those results. And, I repeat, Fried and Wang provide no empirical evidence that the sources and uses of funds that they identity result in innovation and higher wages. My research adduces empirical evidence that just the opposite is often the case.

\section{a. Debt issues by S\&P 500 companies as a source of funds}

Fried and Wang argue that companies recapitalize by repurchasing stock and taking on debt, and that the debt enables the companies to invest in innovation and provide good wages. The debt that they take on offsets to some extent distributions to shareholders. Therefore, by Fried and Wang's account, capital equal to much more than the seven percent of net income that, S\&P 500 companies retained after distributions of dividends and repurchases in the decade 2005-2014 was allegedly available for investment that could result in innovation and good wages

But why do companies issue debt? What uses do their executives have in mind? Conventionally, when companies issue debt for the sake of investment in productive capabilities, that debt leverages retained earnings. Debt that is used for investment in productive capabilities does not replace earnings that have been depleted through buybacks. Innovation entails the development and utilization of productive capabilities in the face of technological, market, and competitive uncertainties. Given that it takes time to develop and utilize these investments in productive capabilities and that there is no guarantee of returns, a company has to be prudent in taking on debt if it wants to avoid cash-flow problems and, possibly, bankruptcy. Hence the need to leverage the debt on a foundation of retained earnings that the company controls.

But a financialized company may take on debt to do stock buybacks for the sake of boosting its stock price. There is considerable evidence that, especially in the low-interest-rate environment that has prevailed since the financial crisis of 2008-2009, U.S. companies have been doing just that. ${ }^{56}$ Companies may also be issuing debt at low interest rates with a view to building up cash

\footnotetext{
${ }^{56}$ Steven C. Johnson and Jennifer Ablan, "Rise of shareholder activism gives bond investors headaches," Reuters, December 19, 2013, at http://www.reuters.com/article/us-investing-activism-bondholders-analys-idUSBRE9BI10420131219; Vivianne Rodrigues, "Bondholders pay price of share buybacks," Financial Times, February 26, 2014, at https://www.ft.com/content/675b7f0a-9e53-11e3-95fe-00144feab7de; ; Justin Lahart, "Share buybacks: The bill is coming due," Wall Street Journal, February 28, 2016, at https://www.wsj.com/articles/share-buybacks-the-bill-is-coming-due1456685173; Tim Melvin, "Beware of firms that borrow cash for stock buybacks," The Street, March 28, 2016, at http://realmoney.thestreet.com/articles/03/28/2016/beware-firms-borrow-cash-stock-buybacks; Michael Mackenzie and Eric Platt, "US corporate bonds: The weight of debt," Financial Times, December 4, 2016, at https://www.ft.com/content/41213b02-b87e-11e6-ba85-95d1533d9a62; Ciara Linnane, "Share buybacks will continue to pose a threat to bondholders in 2017," MarketWatch, January 20, 2017, at http://www.marketwatch.com/story/sharebuybacks-will-continue-posing-a-risk-to-bondholders-in-2017-2017-01-19.
} 
balances so that they can do stock buybacks in the future. We know that as the stock market booms, stock buybacks escalate as companies compete with one another by giving manipulative boosts to their stock prices. They may want to do large open-market repurchases to hit quarterly earnings-per-share (EPS) targets; we do not know to what extent companies engage in this practice because, under Rule 10b-18, the SEC does not require them to disclose the particular days on which they do open-market repurchases. Keeping a readily available pool of cash on hand, even if borrowed, can be very useful to senior executives who want to intervene opportunistically in the workings of the stock market to elevate their company's stock price.

For many corporations, a considerable portion of cash or near-cash reserves is not available for buybacks. Many U.S. corporations borrow to do buybacks in order to avoid repatriating foreign profits on which they would have to pay U.S. corporate taxes. In 1960, at the end of the Eisenhower administration, a change in the tax code whose ostensible purpose was to encourage U.S. multinational corporations to invest in poor countries permitted U.S. companies to defer taxes on corporate profits made abroad until those earnings were repatriated. ${ }^{57}$ The 25 U.S. corporations with the highest accumulated unrepatriated profits at the end of fiscal 2015, as identified in a report by Citizens for Tax Justice, ${ }^{58}$ included 16 of the top 25 repurchasers for the period 2006-2015. Combined, these 25 corporations had an accumulated $\$ 1.488$ trillion in untaxed profits abroad, while at home they did a combined $\$ 1.368$ trillion in buybacks and dispensed $\$ 911$ billion in dividends in the decade 2006-2015.

Cisco Systems, which is high up on the lists of both unrepatriated profits and stock buybacks, is a prime example of a company that keeps its foreign profits offshore while borrowing to do buybacks at home. From 2002 through 2016, Cisco did $\$ 97.5$ billion in buybacks, equal to 95 percent of its net income. It also paid $\$ 18.1$ billion in dividends. At the end of 2016, Cisco's cash and near-cash assets (cash, cash equivalents, and available-for-sale securities holdings) held abroad amounted to $\$ 59.8$ billion, but the company stated that if it were to repatriate these funds, it would have to pay additional U.S. taxes. ${ }^{59}$ The amount of cash and near-cash assets that Cisco held in the United States at the end of 2016 was only $\$ 5.9$ billion.

Therefore, Cisco has had to borrow to sustain its buyback habit. Cisco did the first debt issue in its history in 2006 when it borrowed $\$ 6.5$ billion to acquire Scientific-Atlanta. ${ }^{60}$ Subsequently, through 2016, Cisco issued another $\$ 33.0$ billion in long-term bonds for unstated purposes, while paying back $\$ 11.2$ billion. At the end of 2016, the company had long-term debt of $\$ 28.6$ billion on its books, which, with most of its liquid assets sitting abroad, we can assume had been incurred primarily, and probably entirely, to fund distributions to shareholders. Except for the Scientific-Atlanta acquisition, Cisco has not made use of debt to finance investments in productive capabilities in the United States.

\footnotetext{
${ }^{57}$ William Lazonick, "The real cost of America's global tax dodgers," Salon, August 18, 2011, at http://politics.salon.com/2011/08/18/global_tax_dodgers.

58 Citizens for Tax Justice, “Fortune 500 companies hold a record \$2.4 trillion offshore," CTJ Report, March 3, 2016, at http://ctj.org/pdf/pre0316.pdf.

59 Cisco Systems, Inc., SEC 10-K filing of the year ending July 30, 2016, p. 58.

60 As a company that in the late 1990s had become known as a growth-through-acquisition strategy, Cisco had done nearly all of its acquisitions from 1993 to 2004 using its stock as the combination currency, before turning to the use of cash for its acquisitions. See Carpenter et al., "The Stock Market and Innovative Capability"; Bob Bell, Marie Carpenter, Henrik Glimstedt, and William Lazonick, “Cisco's Evolving Business Model: Do Massive Stock Buybacks Affect Corporate Performance?” Paper presented at the Edith Penrose Centenary Conference, SOAS, University of London, November 15, 2014.
} 


\section{b. Public stock issues by $S \& P 500$ companies as a source of funds}

Fried and Wang posit that, even as S\&P 500 companies do stock buybacks, they have been using stock issues to invest in innovation and provide good wages to their employees. It is, however, unusual for established U.S. companies that are already listed on the stock market to do public stock issues, and when they do, it is rarely to fund investment in innovation. In the late 1920s, as an important example, many established publicly listed companies did large-scale stock issues on the New York Stock Exchange even as they were channeling large sums of surplus cash to speculators, who were buying corporate shares on margin with funds borrowed on the call-loan market at interest rates of 10 to 15 percent. Indeed, the very same corporations that were cashing in by selling shares at highly speculative prices were the main sources of these funds for call loans to speculators. The purpose of these corporate share issues, however, was not to raise funds for new investment in productive capabilities, but rather to take advantage of soaring stockprices driven by stock-market speculation to secure an influx of cash to pay off corporate debt or bolster the corporate treasury. ${ }^{61}$

This type of financial engineering would stand these companies in good stead at the beginning of the 1930s after the economy had moved from boom to bust. In retrospect, this financial behavior contrasts dramatically with the practice of major U.S. corporations over the past two decades of doing large-scale stock repurchases when the stock market is booming for the purpose of pushing up their stock prices - and, with them, executives' stock-based pay. If anything, when boom has turned to bust, some desperate S\&P 500 companies have sought to stay afloat by doing secondary share issues after their stock price had fallen in value. For example, with the bursting of the Internet bubble in 2001-2002, Lucent Technologies, then one of the world's leading telecommunication-equipment companies, found itself with a junk-bond rating and a stock price that had plunged to as low as one percent of its Internet-boom peak. Even as Lucent sold off assets and laid off tens of thousands of employees to avert bankruptcy, it was forced to issue convertible bonds at rock-bottom prices that reflected that of its almost-worthless stock. ${ }^{62}$

As we also know, some corporations are "too big to fail." Included in the Fried and Wang data on stock issues are Wall Street banks that, in need of financial support, issued stock to foreign entities, including sovereign wealth funds, in the run-up to what turned out to be the Great Financial Crisis. Then, once the crisis hit, many of the same banks, in even more desperate need of cash, issued stock to the U.S. government for the purpose of recapitalization. In neither case were the stock issues done to invest in innovation or pay higher wages to workers. Rather the stock issues were done because of the previous profligate behavior of these financial institutions, including massive stock buybacks to boost their stock prices.

Indeed, In September 2008, just after the collapse of Lehman Brothers, which would precipitate the U.S government's Troubled Asset Relief Program (TARP), I wrote about this relation between stock buybacks and stock issues by major U.S. financial institutions in a Financial

\footnotetext{
${ }^{61}$ Gene Smiley and Richard H. Keehn, "Margin Purchases, Brokers' Loans and the Bull Market of the Twenties," Business and Economic History. 2d series. 17, 1988: 129-142.

62 Carpenter et al., "The Stock Market and Innovative Capability"; Lazonick and March, "The Rise and Demise of Lucent Technologies."
} 
Times comment, "Everyone is paying the price for share buy-backs." ${ }^{\circ 3}$ I documented how, in the two years prior to Lehman's collapse, once-powerful Wall Street banks had issued stock to foreign sovereign wealth funds to recover from their reckless behavior in the previous boom years:

In November 2007, the $\$ 7.5$ bn equity investment that Citigroup secured from the Abu Dhabi Investment Authority was almost as much as it spent on buy-backs in 2006 and 2007. Merrill Lynch did more than \$14bn in repurchases in those two years, but by January 2008 had given up a 12.7 per cent equity stake to raise \$9bn from foreign investors. Morgan Stanley, which did over \$7bn in buy-backs in 2006-07, traded a 9.9 per cent equity stake with China's sovereign wealth fund for $\$ 5 \mathrm{bn}$. It has now agreed to a takeover. Lehman Brothers, which repurchased more than $\$ 5$ bn in 2006-07, is now bankrupt.

And when foreign finance could not right these sinking ships, the U.S. government had to step in as the lender of last resort:

The taxpayer is also paying the price of buy-backs. When the US government bailed out Bear Stearns, by assuming the risk of $\$ 29 \mathrm{bn}$ of its subprime mortgage assets, there was almost \$6bn less cash on Bear's balance sheet because of buybacks during 2003-07. So too with the government takeover of Fannie Mae and Freddie Mac, the government sponsored housing entities. They have spent $\$ 10 \mathrm{bn}$ on repurchases since 2003, including \$4bn in 2006-07.

I concluded with a critique of agency theory:

The crisis in the US financial sector demonstrates that the so-called "free cash flow" distributed as buy-backs was not really free. Wall Street banks could use that cash now to avert financial crisis rather than turn to foreign governments and the US taxpayer for a bail-out.

A significant portion of the stock sales that are included in the Fried and Wang data were, therefore, desperation issues as these financial institutions got caught up in the financial maelstrom that they helped to create. And that Financial Times comment predates the TARP bailout. As it turned out, the initial infusions of foreign and U.S.-government cash were insufficient to mitigate the threat of bankruptcy for these financial institutions, and the U.S. Congress had to step in with TARP-resulting in more desperation stock issues that were integrally related to the companies' previous financial behavior, including massive distributions to shareholders. These stock issues had nothing to do with investment in innovation and providing higher wages for employees.

On October 13, 2008, Neel Kashkari, the Treasury official who oversaw the implementation of TARP, outlined its features, including "a standardized program to purchase equity in a broad array of financial institutions. As with the other programs, the equity purchase program will be voluntary and designed with attractive terms to encourage participation from healthy institutions.

\footnotetext{
${ }^{63}$ Lazonick, "Everyone is paying the price."
} 
It will also encourage firms to raise new private capital to complement public capital." ${ }^{\text {, }}$ Under TARP, the U.S. government purchased $\$ 266$ billion in equity in 18 corporations. Included among them were six major Wall Street banks, with the U.S. government investing \$45 billion each in Citibank and Bank of America, \$25 billion each in JPMorgan Chase and Wells Fargo, and $\$ 10$ billion each in Goldman Sachs and Morgan Stanley, for a total of $\$ 160$ billion. ${ }^{65}$ Yet in the decade before the crisis, from 1998 through 2007, these six banks spent a combined \$211 billion on buybacks, equal to 45 percent of net income, along with $\$ 182$ billion on dividends, another 39 percent of net income. These banks did buybacks to manipulate their stock prices, and then had to turn to U.S. taxpayers, who absorbed massive stock issues to bail them out.

Another company that did stock issues induced by the financial crisis was General Electric. In the decade 1998-2007, GE, long one of the biggest repurchasers, recorded buybacks totaling $\$ 74.6$ billion (49 percent of net income) while paying $\$ 62.2$ billion in dividends (another 41 percent of net income). GE's buyback activity continued during the first three quarters of 2008, as the company repurchased $\$ 3.1$ billion in shares at an average price per share of $\$ 31.25$. Then, as the company suffered large losses from its financial arm, GE Capital, it had in October 2008 to issue $\$ 12.0$ billion in common shares at only $\$ 22.25$ per share to retain its bond rating. ${ }^{66}$ During 2008, therefore, GE bought high and sold low. Its stock issue helped GE recover from the financial fiasco of which it was a part. It was not done to invest in innovation or to provide GE employees with higher wages.

The financial crisis also had a severe impact in the U.S. automobile industry, forcing General Motors and Chrysler to turn to the U.S. government for some TARP funding to bail them out. General Motors was a major stock issuer in November 2010, when the "New GM," which had gone bankrupt in 2009, did one of the largest initial public offerings in history, worth \$23.1 billion. ${ }^{67}$ One should also accord this case close scrutiny before assuming, simplistically and without mustering the facts, that stock issues fund investment in innovation and payment of higher wages.

In June and July 2009, the U.S. government had taken the lead in the bailout, which enabled GM to emerge from bankruptcy in just 40 days. U.S. taxpayers put up $\$ 49.5$ billion in rescue funding, ${ }^{68}$ and Canadian taxpayers pitched in another $\$ 10.9$ billion. ${ }^{69}$ The United Auto Workers (UAW) agreed to layoffs and pay cuts worth $\$ 11$ billion. The union-run Voluntary Employee Beneficiary Association (VEBA) was forced to assume GM's pension liabilities in exchange for

\footnotetext{
${ }^{64}$ U.S. Department of the Treasury, "Interim Assistant Secretary for Financial Stability Neel Kashkari Remarks before the Institute of International Bankers," Press Release, October13, 2008, at https://www.treasury.gov/press-center/pressreleases/Pages/hp1199.aspx.

65 "Troubled Asset Relief Program," Wikipedia, at https://en.wikipedia.org/wiki/Troubled_Asset_Relief_Program\#cite_note-ProPublica-TARP-list-46.

66 General Electric, SEC 10-K filing for the year ending December 31, 2008, p. 45.

${ }^{67}$ William Lazonick and Matt Hopkins, "GM's stock buyback is bad for America and the company," Harvard Business Review Blog, March 11, 2015, at https://hbr.org/2015/03/gms-stock-buyback-is-bad-for-america-and-the-company.

${ }^{68}$ Chris Woodyard, "GM bailout played out over five years," USA Today, December 9, 2013, at https://www.usatoday.com/story/money/cars/2013/12/09/gm-bailout-timeline/3929953/.

69 Adrian Morrow and Greg Keenan, "Ontario sells remaining GM shares acquired from bailout", Globe and Mail, February 4 , 2015, at http://www.theglobeandmail.com/report-on-business/ontario-sells-gm-shares-for-11-billion/article22797007/.
} 
shares in the New GM, a step that saved the company $\$ 3$ billion per year. ${ }^{70}$ From 2008 to 2010 , GM's employment was chopped from 243,000 to 202,000.

After taking losses of $\$ 82.1$ billion from 2005 through 2008, GM showed net income of $\$ 6.1$ billion in 2010 and total profits of $\$ 50.0$ billion from 2010 through 2016. Business interests played no role in the equity financing that enabled GM to emerge from bankruptcy and relist on the stock market. In the New GM's 2010 IPO, the U.S. and Canadian governments and the VEBA sold common shares to the public for $\$ 18.1$ billion. GM used the $\$ 4.9$ billion that it netted from a preferred stock issue (with a $4.75 \%$ dividend) to repurchase $\$ 2.1$ billion in outstanding preferred shares held by the U.S. Treasury, with the remaining $\$ 2.8$ billion making up part of a $\$ 4.0$ billion cash contribution to GM's pensions plans for salaried and hourly U.S. workers. ${ }^{71}$ In other words, GM allocated the proceeds from this preferred stock issue to restore some of the funds contributed by two of the parties - U.S. taxpayers and U.S. workers - that had enabled GM to do its IPO.

The longer-run historical context is also important for understanding how a company such as GM got into financial distress to the point that taxpayers and workers found themselves in the position of having to keep the company from liquidating. Many factors were involved, but buybacks played a role. As I wrote in a BusinessWeek article in the immediate aftermath of GM's emergence from bankruptcy in 2009: "If bailed-out General Motors (GM) had banked the \$20.4 billion distributed to shareholders as buybacks from 1986 through 2002 (with a 2.5\% aftertax annual return), it would have had $\$ 35$ billion in 2009 to stave off bankruptcy and respond to global competition.",72

Or as Bob Lutz, the veteran auto executive, put it when new pressure was placed on GM to repurchase its stock in 2015, stock buybacks are "always a harbinger of the next downturn...in almost all cases, you regret it later." 73 Since 2015, on the insistence of a group of hedge funds and their front man-one Harry J. Wilson - the now-profitable GM has been doing buybacks again, to the tune of $\$ 6.0$ billion in buybacks in 2015-2016. In 2009 Wilson had been a central figure in the Obama bailout task force, from which position he insisted, over objections from labor and taxpayer interests, that the bailout should be done with equity, not debt. ${ }^{74}$

If the bailout had been done with debt, the U.S. government would have been GM's senior creditor, and the U.S. taxpayer would have had to be made whole on this debt or the company could have been forced into bankruptcy again. As it was, after GM went public in $2010,{ }^{75}$ the U.S. government was the company's biggest shareholder (even after an initial sale of a portion of its shares in the IPO), and Wall Street began calling the reemerged company "Government Motors," insisting that the U.S. Treasury sell its stake as soon as possible. The U.S. government

\footnotetext{
70 Lazonick and Hopkins, "GM's stock buyback."

${ }^{71}$ General Motors, SEC 10-K filing for year ending December 31, 2011, p. 21

72 Lazonick, "The buyback boondoggle,"

${ }^{73}$ Mike Spector and Joanne S. Lublin, "Bailout architect presses GM," Wall Street Journal, February 10, 2015, at https://www.wsj.com/articles/gm-shareholder-seeks-spot-on-board-1423577927.

74 Lazonick and Hopkins, "GM's stock buyback."

${ }^{75}$ Clare Baldwin and Soyoung Kim, “GM IPO raises $\$ 20.1$ billion," Reuters, November 17, 2010, at http://www.reuters.com/article/us-gm-ipo-idUSTRE6AB43H20101117.
} 
sold the last of its shares in December 2013, at a loss to U.S. taxpayers of $\$ 11.2$ billion. $^{76}$ It has been estimated that GM workers gave up multiples of that amount in layoffs, wage cuts, and reduced benefits to help finance the rebirth of the company. ${ }^{77}$

Meanwhile, with the aid of taxpayer subsidies and union concessions, as well as the growth of the China market and a bankruptcy-induced focus on innovation, GM was profitable from 2010 - and, in January 2015, Harry J. Wilson - the very same man who has designed the Obama's administration's 2009 bailout of GM-showed up in GM CEO Mary Barra's office representing the hedge funds that had purchased shares outstanding on the stock market. On their behalf, and with a handsome cut for himself, Wilson demanded that GM do $\$ 8$ billion in buybacks and put him on the GM board. Unlike the U.S. and Canadian governments and the UAW, the hedge funds that Wilson represented had not invested any money in GM in bringing the company out of bankruptcy in 2009 or in putting the company in position to do its 2010 IPO. Yet now, through their duplicitous mouthpiece, these hedge funds were asserting their right to financial "returns" through buybacks, as well as participation in strategic control by occupying a seat on the board. In the event, GM and Wilson agreed to a \$5-billion buyback but no board seat.

If GM's 2010 stock issue, therefore, provided the New GM with funds for investment in productive capabilities, it was because taxpayers and workers, not public shareholders, had made the New GM possible. And if the bailout had been done with debt rather than equity, taxpayers and workers would have benefited far more from GM's return to profitability, if only because they could have then insisted on recouping their own investments in the restructuring before parasitical shareholder activists could get their greedy hands on corporate profits that they had played absolutely no role in generating.

Nor, as in most cases in which predatory value extractors have used distributions to shareholders to line their own pockets with returns to investment in productive capabilities that should have gone to taxpayers and workers, were the gains to the value extractors the result of "market forces." Rather, the predators used their power to influence the corporate allocation of resources and returns. Agency theorists such as Fried and Wang assume that these resource-allocation decisions result in superior economic outcomes, i.e., innovation and higher wages. Neither facts nor logic are on their side.

\section{c. Internal stock issues for stock-based pay as a use of funds}

If some of the largest and best-known cases of public stock issues over the past decade fail to support the Fried and Wang argument, the fact is that the vast majority of the cash from stock issues in the data for S\&P 500 companies that they present did not come from stock-market sales to the public. They came, rather, from sales of shares to employees exercising their stock options or taking advantage of an employee stock-purchase program. In the case of a stock option, the amount of cash raised depends on the option exercise price, which is the market price of the stock on the grant date. In the case of an employee stock purchase, the amount of cash raised is

\footnotetext{
${ }^{76}$ Eric Beech, "U.S. government says that it lost $\$ 11.2$ billion on GM bailout," Reuters, April 30, 2014, at http://www.reuters.com/article/us-autos-gm-treasury-idUSBREA3T0MR20140430.

77 Lazonick and Hopkins, "GM's stock buyback."
} 
customarily at 85 percent of the market value of shares on the date that the stock is purchased. ${ }^{78}$ For example, in fiscal 2016 Cisco, a company that is well known for using a broad-based stockoption plan, secured $\$ 1.1$ billion from the sale of shares to its employees, of which $\$ 615$ million (32 million shares) came from stock options and the remainder (25 million shares) from the employee stock-purchase plan at 85 percent of the market price.

Recognizing the importance of stock issues to employees as a source of equity funds, Fried and Wang argue that stock-based pay is one way in which a company uses stock buybacks to provide "good wages" to employees. As they state:

Recall that one of the main concerns raised about buybacks is that they give shareholders capital while leaving "very little for... higher incomes for employees" (Lazonick, 2014). However, one of the most important reasons firms repurchase stock is to acquire shares to pay employees (Kahle, 2002; Bens et al., 2003). For such compensation-driven repurchases, the cash that flows out to public shareholders in the repurchase leg of the transaction finds its way to employees when they get the repurchased shares and sell them back to public shareholders. ${ }^{79}$

Fried and Wang are correct to point to the link between stock-based pay for a broad base of employees and the buyback activities of the companies that employ them. I have done a great deal of research and writing on the subject. ${ }^{80}$ In a paper entitled "Skill Development and Sustainable Prosperity: Collective and Cumulative Careers versus Skill-Biased Technical Change," Lazonick and co-authors argue: "An analysis of the role of stock options as a component of pay for a broad base of employees is of utmost importance for understanding the relation between productivity and 'wages' for employees at high-tech companies." ${ }^{\text {" } 1 ~}$ But the relation between buybacks and employee incomes is much more complicated than the simple "flow-of-funds" model that Fried and Wang lay out. ${ }^{82}$ Especially when the stock market is volatile, the use of stock options as a component of pay for a broad base of workers is fraught with problems for an innovative enterprise.

\footnotetext{
${ }^{78}$ Jonathan Burton, “Cash in the cubicle," MarketWatch, December 2, 2003, at http://www.marketwatch.com/story/employeestock-purchase-plans-are-worth-every-dollar.

79 Fried and Wang add a footnote: 16: "Repurchases are not necessary to provide shares for employee stock compensation arrangements. In principle, a firm could use only newly issued shares to pay employees and, when it reaches the shareauthorization limit in its corporate charter, seek shareholder approval to increase that limit (Fried, 2005). However, for a variety of reasons, firms will generally use repurchases to acquire at least some of the shares given to employees."

${ }^{80}$ See William Lazonick, Sustainable Prosperity in the New Economy? Business Organization and High-Tech Employment in the United States, W. E. Upjohn Institute for Employment Research, 2009, ch. 2; William Lazonick, "The New Economy Business Model and the Crisis of US Capitalism," Capitalism and Society, 4, 2, 2009: article 4; William Lazonick, "The Explosion of Executive Pay and the Erosion of American Prosperity," Entreprises et Histoire, 57, 2009: 141-164; Hopkins and Lazonick, "The Mismeasure of Mammon."

${ }^{81}$ William Lazonick, Philip Moss, Hal Salzman, and Öner Tulum "Skill Development and Sustainable Prosperity: Collective and Cumulative Careers versus Skill-Biased Technical Change," Institute for New Economic Thinking Working Group on the Political Economy of Distribution Working Paper No. 7, December 2014, at https://ineteconomics.org/ideas-papers/researchpapers/skill-development-and-sustainable-prosperity-cumulative-and-collective-careers-versus-skill-biased-technical-change, p. 34, The following arguments on the stock options as a component of high-tech workers' pay draws heavily on this paper.

82 Of course, in making their "good wages" argument, Fried and Wang could have consulted the research cited in the previous notes, but from their treatment of the question, there is no evidence that they have.
} 
First, historically the use of stock options for a broad base of employees by "New Economy" startups came at the cost of the high-tech personnel eschewing the "Old Economy" norm of employment security with one company over the course of a career. The use of broad-based stock-option plans spread rapidly in the 1980s and 1990s as a mode of pay with which, in venture-backed high-tech industries - in particular, information and communications technology (ICT) and biotechnology-New Economy startups could lure professional, technical, and administrative employees away from established Old Economy firms, at which a "career-withone-company" was the norm. By the 2000s, the career-with-one-company norm was largely gone not only in these high-tech industries but across U.S. business, exposing even college-educated workers to high levels of employment insecurity and, often, truncated careers when the companies for which they worked turned from retain-and-reinvest to downsize-and-distribute. ${ }^{83}$

Second, at certain high-tech companies during the Internet boom of 1996-2000, employees' gains from exercising stock options were so high that they fostered a hypermobility of labor that undermined the commitment of these employees to engaging in the collective and cumulative learning processes that are central to innovation. For example, at Microsoft, the average gains per employee (excluding the CEO and other four highest-paid executives) from exercising stock options were $\$ 79,000$ across 19,200 employees in 1996 . Then these gains soared to $\$ 369,700$ across 29,200 employees in 1999 and $\$ 449,100$ across 35,200 employees in 2000, before declining to $\$ 80,300$ across 52,800 employees in 2003. It is said that in 2000 alone 10,000 Microsoft millionaires were created, many of whom quit Microsoft to become angel investors, found or join startups, or retire at an early age. This hypermobility of labor disrupted projects at Microsoft Research, which had been founded in 1991, and helped to ensure that the company would not be a leader in innovation in the 2000 s and beyond. ${ }^{84}$

Third, major differences in earnings from stock options, both across employees in a particular company and over time, may be caused by stock-market volatility and have nothing to do with differences in productive contributions. In the Microsoft example, since options take at least one year to vest, an employee with years of career experience who joined the company in 2000 would miss out on the stock-option-gains bonanza reaped by many employees with less career experience who had joined the company in earlier years. An advantage of stock-based pay for the company is that the funding of employee gains comes not from its internal cash flow but rather from the pockets of stock-market traders who have bid up the company's stock price. This "outsourcing" of pay determination to the oft-volatile stock market, which is driven by a combination of innovation, speculation, and manipulation, is bound to generate substantial pay inequities because of the timing and circumstances under which employees join a company, receive their options, and have the opportunity to exercise them.

Fourth, high-tech companies often say that they are doing buybacks to offset dilution of shareholding caused by their broad-based stock-option plans. But the number of shares repurchased is generally a multiple of the number of shares issued when employees exercise stock options. Moreover, companies typically repurchase shares when stock prices are high, making this mode of employee pay very expensive. ${ }^{85}$ In short, employee stock options may

\footnotetext{
${ }^{83}$ Lazonick, Sustainable Prosperity in the New Economy?.

84 Ibid., ch. 2.

85 Lazonick, "Stock Buybacks."
} 
generate high pay for some non-executive workers at certain times and places, but this mode of compensation is often part of the problem of the financialized corporation. Moreover, the use of broad-based stock-option plans has encouraged the tendency of U.S. high-tech companies to look to buybacks to manipulate their stock prices while often undermining the organizational integration and financial commitment that innovation requires.

Obviously, the gains from exercising stock options depend on the trajectory of a company's stock price. If the stock price were to reflect only the company's innovative success, one might argue that an employee's gains from exercising stock options represent a way in which he or she shares in that success. The problem is that, besides by innovation, a company's stock price may be determined by speculation and manipulation. As a result, the gains from exercising stock options can become detached from the innovative performance of the firm.

\section{d) $R \& D$ as a use of funds for innovation}

Fried and Wang argue:

The focus on shareholder payouts as a percentage of net income is highly misleading; it wrongly implies that "net income" reflects the totality of a firm's resources that are generated from its business operations and are available for investment. In fact, net income is calculated by subtracting the many costs associated with future-oriented activities that can be expensed (such as R\&D). These amounts are substantial. Firm spending on R\&D is, on average, equal to about $25-30 \%$ of net income. In other words, much of the resources generated by a firm's business operations have already been used for long-term investment before net income is calculated. Indeed, a firm that spends more on R\&D will, everything else equal, have a lower net income and a higher shareholder-payout ratio. At most, net income indicates the additional resources generated by a firm's business operations that are available for (a) investment activities whose cost must be capitalized rather than expensed and (b) additional R\&D and other activities whose costs are expensed.

Some basic facts about R\&D spending make it clear that there are a number of problems with the Fried and Wang argument. Investments in R\&D are concentrated in a few sectors of the economy: ICT, pharma, and aerospace. The companies in the S\&P 500 Index in January 2016 recorded a total of $\$ 250.4$ billion in R\&D expenditures for fiscal 2015 . But 289 of the 500 companies recorded zero $R \& D$ expenses, with the $\mathrm{R} \& \mathrm{D}$ expenditures of the other 211 companies ranging from $\$ 16.0$ million to $\$ 12.5$ billion. Of the companies that recorded R\&D expenditures, 15 companies with $\$ 5$ billion or more did 49 percent of the total R\&D spending in 2015 , while another 40 companies with between $\$ 1$ billion and $\$ 5$ billion in $R \& D$ expenditures accounted for another 35 percent of total R\&D spending. ${ }^{86}$ The R\&D leader was Amazon, which did not do any buybacks or dispense dividends from 2013 through 2016 as it ramped up its R\&D spending

\footnotetext{
${ }^{86}$ For R\&D spending in the U.S. economy more generally, see Matt Hopkins and William Lazonick, "Who Invests in the HighTech Knowledge Base?" Institute for New Economic Thinking Working Group on the Political Economy of Distribution Working Paper No. 6, September 2014 (revised December 2014), at https://ineteconomics.org/ideas-papers/researchpapers/who-invests-in-the-high-tech-knowledge-base;
} 
from $\$ 4.6$ billion in 2012 to $\$ 16.1$ billion in 2016. In contrast, Microsoft, perennially among the largest repurchasers, was no. 4 in R\&D spending ( $\$ 12.0$ billion) in 2015, a year in which it also did $\$ 14.4$ billion in buybacks and $\$ 9.9$ billion in dividends, which combined equalled 199 percent of its net income.

The argument that $\mathrm{R} \& \mathrm{D}$ spending funds innovation and higher wages is applicable, therefore, to a specific set of companies, among which - because of both business strategy and stages of development-there may be very different relations between R\&D expenditures and distributions to shareholders. Understanding the relation between buybacks and R\&D spending requires the accumulation of case-study research of companies in R\&D-intensive sectors. For example, in 2005-2007, following the success of its 2G Razr cellphone, Motorola did \$7.8 in buybacks, equivalent to 94 percent of net income, along with $\$ 1.3$ billion in dividends, and then failed to compete in $3 \mathrm{G}$ phones. Losing $\$ 4.3$ billion in 2007-2009, Motorola slashed R\&D expenditures from $\$ 4.5$ billion in 2007 to $\$ 2.5$ billion in 2010 . The company was divided the next year into Motorola Solutions and Motorola Mobility, which became part of the Chinese computer company Lenovo in 2014. It is worth noting that in 2007 corporate predator Carl Icahn took a large position in Motorola stock, attracted by the fact that the company had made $\$ 8.2$ billion in profits and done $\$ 4.7$ billion in buybacks in $2005-2006$. Icahn did not originate the pattern of corporate resource allocation that resulted in Motorola's downfall, but he helped to ensure that it remained on its "downsize-and-distribute" path.

At the same time, it is at best naïve for Fried and Wang to assume, as they do, that $R \& D$ expenditures will necessarily result in innovation and higher wages. Indeed, it is surprising to see them make this assumption because it is a basic tenet of agency theory-as espoused, for example, in the 2004 Bebchuk and Fried book - that R\&D spending is one way in which corporate executives seek to "build empires" at the expense of "shareholder value." The fact is that innovation is a process that is uncertain, collective, and cumulative. If a high-tech company does not invest in $R \& D$, it will certainly fail to be innovative. But if a company does invest in $\mathrm{R} \& \mathrm{D}$, then it needs to ensure that the social conditions of innovative enterprise-strategic control, organizational integration, and financial commitment-support the uncertain, collective and cumulative processes that can transform $R \& D$ expenditures into higher-quality, lower-cost products than were previously available.

When, however, strategic control is in the hands of corporate executives and activist shareholders who have neither the incentive nor the ability to invest in innovation, we should expect that those investments in R\&D will fail. Moreover, when these strategic decision-makers allocate resources in ways that undermine the collective and cumulative learning that is the essence of innovation, organizational integration as a condition of innovative enterprise weakens. Furthermore, even if the financialized company does show high levels of R\&D spending — often to convince the stock market that, notwithstanding massive distributions to shareholders, it is still a high-tech company - these distributions to shareholders tend to undercut not only the efficacy of organizational learning but also the financial commitment to sustaining all of the non-R\&D functions that an innovative enterprise requires to generate competitive products. 


\section{e) Acquisitions as a use of funds for innovation}

Fried and Wang argue:

Even net shareholder payouts (adjusted for net debt issuances) tell us little about the effect of such capital flows on public firms' financial capacities-because firms can always choose to issue more stock. The amount of equity issued by any given public firm in any given year does not represent a cap; the firm could have chosen to issue even more stock to raise cash, acquire assets, or pay employees. Thus, if that firm has a valuable investment opportunity, but little cash, the firm should generally be able to use equity financing to exploit the opportunity. As long as a firm can issue more shares, even firm-shrinking net shareholder payouts (those not offset by net debt issuances) cannot impair the firm's subsequent ability to invest, innovate, and grow.

Here again, it is surprising to see agency theorists arguing that if a company uses its stock, with its price elevated by buybacks, as an acquisition currency, the result will be innovation and higher wages. I would expect agency theorists to assume that, in doing stock-based acquisitions, senior executives are engaged in diluting shareholding in order to build their personal empires. And again, from the perspective of The Theory of Innovative Enterprise, one would not make the assumption that acquisitions, however they are financed, will result in innovation and higher wages unless the social conditions of innovative enterprise-strategic control, organizational integration, and financial commitment-are in place to support the transformation of the acquired capabilities into higher-quality, lower-cost products than had previously been available. As we have shown in our research on innovation and competition in the global communicationtechnology industry, a theory of innovative enterprise is required to perform the analysis of the social conditions under which some acquisitions succeed and others fail. ${ }^{87}$

Cisco Systems is a prime example of a company that effectively used stock as an acquisition currency, as it did in the period 1993-2000 when it came to dominate enterprise equipment, but then afterwards, as it did massive buybacks, failed to invest sufficiently in developing the productive capabilities of key service-provider-equipment acquisitions it had made in 19982000. As we have shown in an in-depth study of the company, Cisco's acquisitions from 2004 on were done mostly with cash because, with all its buybacks, it did not want to dilute shareholding. Moreover, many of the acquisitions that Cisco did in the 2000s to expand its product offerings generated nothing more than commodities, an outcome that we attribute to CEO John Chambers' obsessive focus on doing buybacks to manipulate the company's stock price. ${ }^{88}$ We have also shown how the leading Old Economy communication-equipment companies Lucent Technologies and Nortel Networks sought to imitate the Cisco model of growth-through-

\footnotetext{
${ }^{87}$ See Marie Carpenter and William Lazonick, "Innovation, Competition and Financialization in the Communications Technology Industry: 1996-2016," paper prepared for the European Commission Horizon 2020 Project, Innovation-Fueled Sustainable, Inclusive Growth, May 22, 2017, at http://www.isigrowth.eu/2017/06/14/innovation-competition-and-financialization-inthe-communications-technology-industry-1996-2016/.

88 Bell et al., "Cisco's Evolving Business Model."
} 
acquisition-and-integration in the late 1990s, using stock as an acquisition currency, and destroyed themselves in the process. ${ }^{89}$

There is no reason to assume, as Fried and Wang do, that any acquisition, however it is financed, will result in innovation and higher wages. Recent examples of disastrous deals by major technology companies are Hewlett-Packard's acquisition of the British software company Autonomy and Microsoft's acquisition of Nokia's cellphone business. HP's acquisition of Autonomy in August 2011 was done for \$10.2 billion in cash from its offshore holdings, which were protected from U.S. corporate taxation as long as the profits were not repatriated. ${ }^{90}$ In November 2012, HP announced that it was taking an $\$ 8.8$ billion accounting charge because of the failure of the acquisition. ${ }^{91}$ Microsoft's acquisition of Nokia's cellphone business followed a strikingly similar trajectory. The acquisition, which included 25,000 Nokia employees, was done in September 2013 for \$7.2 billion in cash from Microsoft's offshore holdings. ${ }^{92}$ By May 2016 the Nokia acquisition was deemed a failure, with Microsoft losing about $\$ 8$ billion because of write-offs and restructuring (i.e., layoff) charges. ${ }^{93}$

Fried and Wang are correct: A company can use its stock as an acquisition currency. But they have no grounds for assuming that a) the use of stock or cash is independent of a company's policy for distributing cash to shareholders, or b) all acquisitions result in innovation and higher wages. Lacking a theory of the value-creating company, in this, as in other parts of their discussion of the sources and uses of funds, Fried and Wang make statements that defy both facts and logic.

\section{f) Venture capital as a use of funds for innovation}

Fried and Wang argue:

The concern about the volume of shareholder payouts appears to be based, in part, on an implicit assumption that there is no economic benefit to putting cash in the hands of public shareholders. But net shareholder payouts from public companies do not disappear down the economic drain. Just as much of the net shareholder payouts from S\&P 500 firms flow to smaller public firms outside the S\&P 500, much of the net shareholder payouts from public companies in the aggregate are

${ }^{89}$ Carpenter et al., "The Stock Market and Innovative Capability"; Lazonick and March, "The Rise and Demise of Lucent Technologies."

90 "HP to Acquire Leading Enterprise Information Management Software Company Autonomy Corporation plc," HP press release, August 18, 2011, at http://www8.hp.com/in/en/hp-news/press-release.html?id=1051736\#.WWYQT9N94nM

${ }^{91}$ Robert Armstrong and Stuart Kirk, “HP and Autonomy: how to lose \$8.8bn," Financial Times, May 8, 2013, at https://www.ft.com/content/7a52adb4-b70d-11e2-a249-00144feabdc0.

92 “Microsoft to acquire Nokia's devices \& services business, license Nokia's patents and mapping services," Microsoft press release, September 3, 2013, at https://news.microsoft.com/2013/09/03/microsoft-to-acquire-nokias-devices-servicesbusiness-license-nokias-patents-and-mapping-services/\#pBTLPTPvpcDsUDvR.97; Gerard J. Tellis, “Microsoft and Nokia: A marriage made in hell," Forbes, September 4, 2013, at https://www.forbes.com/forbes/welcome/?toURL=https://www.forbes.com/sites/forbesleadershipforum/2013/09/04/micr osoft-and-nokia-a-marriage-made-in-hell/\&refURL=\&referrer=\#4f1ed935536b. .

93 Gregg Keizer, “Microsoft writes off \$7.6B., admits failure if Nokia acquisition," Computerworld, July 8, 2015, at http://www.computerworld.com/article/2945371/smartphones/microsoft-writes-off-76b-admits-failure-of-nokiaacquisition.html; Tom Warren, "Microsoft wasted at least \$8 billion on its failed Nokia experiment," The Verge, May 25, 2016, at https://www.theverge.com/2016/5/25/11766540/microsoft-nokia-acquisition-costs. 
likely to be invested in firms raising capital through an IPO, or in non-public businesses backed by private equity or venture capital. Historically, these firms have been generators of tremendous innovation and job growth in the U.S. economy. Thus, even if net shareholder payouts were to reduce public firms' ability to invest, innovate, and provide higher wages, some of these funds will find their way to private firms and enable these firms to invest, innovate, and provide higher wages. In short, any economic costs borne by stakeholders of public firms as a result of net shareholder payouts must be weighed against the economic benefits generated by the investment of at least some of these funds in private firms.

Do the massive distributions to shareholders done by established companies such as those included in the S\&P 500 Index provide funds to U.S. venture capitalists that enable them to back new firms? As funds flow through the economy, there is no doubt that some of the dividends that shareholders receive for holding shares and some of the stock-price gains that some shareholders reap when they sell shares whose prices have been boosted by buybacks end up in venturecapital funds. But Fried and Wang offer no solid evidence that U.S. venture capital relies on these massive distributions to shareholders as significant sources of funds. ${ }^{94}$

The limited-partnership business model that would come to dominate the U.S venture-capital industry was first set up in 1959 with the launch of the firm of Draper, Gaither, and Anderson in Palo Alto, CA, with funding of \$6 million from the Rockefeller Brothers, Lazard Freres, and some wealthy individuals. ${ }^{95}$ Even in the 1970s, when, centered in Silicon Valley, venture capital evolved into a distinctive industry to fund new-firm creation, institutional investor funding remained scarce. ${ }^{96}$ That changed after July 1979 when the U.S. Department of Labor clarified that pension-fund managers could allocate up to five percent of a fund's assets to risky investments such as venture funds without transgressing the "prudent man" rule contained in the Employee Retirement Income Security Act (ERISA) of 1974. As a result, pension-fund money poured into venture-capital funds. Limited venture-capital partnerships of the type that prevailed in Silicon Valley increased their access to the capital of pension funds from (measured in 1997 dollars) \$69 million in 1978, just 15 percent of all funds raised, to \$1,808 million in 1983. Throughout the 1980s and 1990s, pension funds provided anywhere from 31 percent to 59 percent of the funds raised by limited partnerships, which in turn increased their share of all venture funds raised from 40 percent in 1980 to 80 percent a decade later. $^{97}$

Especially after the Apple and Genentech IPOs of 1980, there was far more venture capital available than good projects in which to invest. One of the chapters of a well-known book, The New Venturers, written by BusinessWeek reporter John Wilson in 1985, is titled "Vulture Capital," signifying the extent to which the flooding of funds into the industry in the first half of the 1980s resulted in too much money chasing too few good startup opportunities. The same

\footnotetext{
${ }^{94}$ See Lazonick, Sustainable Prosperity in the New Economy?; Lazonick, "The New Economy Business Model”; William Lazonick and Öner Tulum, "US Biopharmaceutical Finance and the Sustainability of the Biotech Business Model," Research Policy, 40, 9, 2011: 1170-1187; Lazonick, "The Functions of the Stock Market."

95 "Blue-Ribbon Venture Capital," Business Week, October 29, 1960.

${ }^{96}$ Lazonick, Sustainable Prosperity in the New Economy?, ch. 2.

${ }^{97}$ Paul Gompers and Josh Lerner, The Venture Capital Cycle, MIT Press, 2002, p. 8.
} 
problem, which appeared on a gigantic scale during the dot.com boom of the late $1990 \mathrm{~s},{ }^{98}$ exists today in the biomedical industry. In a phenomenon that Lazonick and co-authors Mustafa Erdem Sakinç and Öner Tulum call "product-less IPOs" or "PLIPOs," biomedical startups with no commercial product become listed on NASDAQ, which enables stock-market speculators and manipulators - including top executives, board members, venture capitalists, and hedge-fund managers - to make vast amounts of money even when no innovative product is forthcoming. ${ }^{99}$

The new ventures that do evolve into innovative going concerns achieve this outcome through a regime of "retain-and-reinvest" in which, in order to grow, they tend to pay no dividends and do few if any buybacks. ${ }^{100}$ But given the critical role of the stock market — in such instances, almost invariably NASDAQ - in providing "exit" opportunities for both venture-capital investments and employee stock options, when New Economy companies such as Intel, Microsoft, Oracle, and Cisco become successful, concern with keeping down the volume of outstanding shares turns them into rabid stock repurchasers. Finally, there is no evidence that the "war chests" hedge-fund activists build up by buying and selling shares of companies that do massive distributions to shareholders represent a significant source of venture capital for building new companies. There is, on the contrary, abundant evidence that activists fill their war chests, and increase their own personal wealth, by tearing apart established companies, helping to create the enormous imbalance between value creation and value extraction that has become a characteristic feature of the unstable and inequitable U.S. economy. ${ }^{101}$

\section{Replace Agency Theory with Innovation Theory}

For about three decades after World War II, the United States consolidated its position as the world's leading economic power, driven by business enterprises that engaged in "retain-andreinvest." During these decades, the distribution of income became somewhat more equal and a middle class of both high-school-educated blue-collar workers and college-educated white-collar workers thrived. Over the past four decades, in contrast, the United States has experienced extreme concentration of income among the richest households and the erosion of middle-class employment opportunities for the vast majority of the population. ${ }^{102}$

These two economic problems are integrally related, as, under the influence of the mantra that companies should be run to "maximize shareholder value," the resource-allocation regimes of business corporations have shifted from retain-and-reinvest to downsize-and-distribute. ${ }^{103}$ With the rise of ultra-aggressive hedge-fund activism, the current period of U.S. economic history can be called "The Era of Predatory Value Extraction." In a forthcoming book, Jang-Sup Shin and I analyze the perpetrators of this predation as a concatenation consisting of senior executives as

\footnotetext{
${ }^{98}$ John Cassidy, Dot.Con: The Greatest Story Ever Sold, Harper, 2002; Mark Gimein, "You bought. They sold." Fortune, September 2, 2002, at http://www.markgimein.com/pages/greed.pdf.

99 Lazonick and Tulum, "US Biopharmaceutical Finance"; William Lazonick, Matt Hopkins, Ken Jacobson, Mustafa Erdem Sakinç, and Öner Tulum, "U.S. Pharma's Financialized Business Model," Institute for New Economic Thinking Working Paper No. 60, June 25, 2017, at https://www.ineteconomics.org/research/research-papers/us-pharmas-financialized-business-model.

${ }^{100}$ See our study of what happened to Apple when, in the decade after Steve Jobs left the company in 1985, its senior executives became obsessed with MSV. Lazonick et al., "Apple's Changing Business Model."

${ }^{101}$ Lazonick, "Profits Without Prosperity"; Lazonick, "Labor in the Twenty-First Century"; Lazonick and Shin, "Rebalancing Value Creation and Value Extraction."

102 Lazonick, "Labor in the Twenty-First Century."

${ }^{103}$ Lazonick and O’Sullivan, "Maximizing Shareholder Value"; Lazonick, "Stock Buybacks."
} 
value-extracting insiders, institutional investors as value-extracting enablers, and activist shareholders as value-extracting outsiders. ${ }^{104}$

Academics have played an important role as agents of activist aggression. Since the 1970s, agency theory has aided and abetted predatory value extraction by providing an ostensible economic rationale for why what I have called the legalized looting of the business corporation should result in the more efficient allocation of society's economic resources. Fundamental to agency theory is the argument that shareholders as principals need to rely on managers as agents to make decisions concerning corporate-resource allocation. Agency theory contends that the efficient allocation of economic resources requires governance structures that maximize the economic value that accrues to shareholders. If, as a result, the distribution of income is highly unequal, so the agency story goes, that is because economic efficiency requires extreme inequality.

The agency-theory argument raises two critical and related questions: Why are public shareholders deemed to be the "principals" in whose interests the firm should be run? And what contributions do public shareholders make to the value-creation process? The answers to these questions expose agency theory's logical and factual flaws.

Agency theory's answer to the first question is that only shareholders invest in the firm, while all other participants in the firm provide marketable inputs for which they are paid marketdetermined prices. Its answer to the second question is that, having invested in the firm, public shareholders take the risks of whether those investments will yield profits or losses, and hence, for the sake of economic efficiency, only shareholders have a claim on the firm's profits if and when there is a positive "residual" of revenues over costs.

In the introduction to this essay and elsewhere I have spelled out the logical and factual flaws in these answers. ${ }^{105}$ In brief, public shareholders do not, as a rule, invest in the firm. They invest in shares outstanding by simply purchasing them on the stock market. And in purchasing shares on a liquid stock market such as the New York Stock Exchange or NASDAQ, public shareholders take little risk because they enjoy limited liability if they hold the shares while, at any instant and at a very low cost, they can sell the shares at the going market price.

Public shareholders are portfolio investors, not direct investors. The generation of innovative products, however, requires direct investment in productive capabilities. These investments in innovation are uncertain, collective, and cumulative. Innovative enterprise requires strategic control to confront uncertainty, organizational integration to engage in collective learning, and financial commitment to sustain cumulative learning. That is why, to understand the productivity of the firm, we need a theory of innovative enterprise.

When, as in the case of a startup, financiers make equity investments in the absence of a liquid market for the company's shares, they are direct investors who face the risk that the firm will not be able to generate a competitive product. The existence of a highly speculative and liquid stock market may enable them to reap financial returns - in some cases, even before a competitive

\footnotetext{
104 Lazonick and Shin, "Rebalancing Value Creation and Value Extraction."

${ }^{105}$ See Lazonick, "The Functions of the Stock Market" for a complete statement of the argument.
} 
product has been produced. It was to make such a speculative and liquid market available to private-equity investors, who were to become known as "venture capitalists," that in 1971 the National Association of Security Dealers Automated Quotation exchange was launched by electronically linking the previously fragmented, and hence relatively illiquid, Over-the-Counter markets. NASDAQ became an inducement to direct investment in startups precisely because it offered the prospect of a quick IPO; one that could take place within a few years after the founding of the firm.

It is for that reason that venture capitalists call a listing on NASDAQ an "exit strategy." In effect, they are exiting their illiquid, high-risk direct investments by turning them into liquid, low-risk portfolio investments. If, after an IPO, the former direct investors decide to hold onto their shares, they are in precisely in the same low-risk portfolio-investor position as any other public shareholders: they can use the stock market to buy and sell shares whenever they so choose.

But, as also discussed at the outset of this essay, venture capitalists are not the only economic actors who bear the risk of making direct investments in productive capabilities. Taxpayers through government agencies and workers through the firms that employ them make risky investments in productive capabilities on a regular basis. From this perspective, households as taxpayers and workers may have, by agency theory's own logic, "residual claimant" status: that is, an economic claim on the distribution of profits if and when they occur.

Through government investments and subsidies, taxpayers regularly provide productive resources to companies without a guaranteed return. As an important example, but only one of many, the 2016 budget of the U.S. National Institutes of Health (NIH) was \$32.3 billion, part of a total NIH investment in life-sciences research spanning 1938 through 2016 that added up to just under $\$ 1$ trillion in 2016 dollars. ${ }^{106}$ Businesses that make use of life-sciences research benefit from the public knowledge that the NIH generates. As risk bearers, taxpayers who fund such investments in the knowledge base, or physical infrastructure such as roads, have a claim on corporate profits if and when they are generated. Through the tax system, governments, representing households as taxpayers, seek to extract this return from corporations that reap the rewards of government spending. However, tax revenues on the prospective gains from innovation depend on the success of innovative enterprise while, through the political process, tax rates on those gains are subject to change. Hence, for both economic and political reasons, the returns to taxpayers whose money has been invested for the benefit of business enterprises are by no means guaranteed.

Workers regularly make productive contributions to the companies for which they work through the exercise of skill and effort beyond those levels required to lay claim to their current pay, but without guaranteed returns. ${ }^{107}$ Any employer who is seeking to generate a higher-quality, lowercost product knows the profound difference in the productivity levels of those employees who just punch the clock to get their daily pay and those who engage in learning that allows them to make productive contributions through which they can build their careers, thereby putting

\footnotetext{
106 National Institutes of Health, "Budget," at http://www.nih.gov/about-nih/what-we-do/budget. See also Lazonick and Tulum, "US Biopharmaceutical Finance."

107 William Lazonick, Competitive Advantage on the Shop Floor, Harvard University Press, 1990; Lazonick, "The Theory of Innovative Enterprise."
} 
themselves in a position to reap future returns in work and in retirement. Yet these careers and the returns that they can generate are not guaranteed, and under the downsize-and-distribute resource-allocation regime that MSV ideology-legitimized by agency theory-has helped put in place, these returns and careers have, in fact, been undermined.

As risk bearers, therefore, taxpayers whose money supports business enterprises and workers whose efforts generate productivity improvements have claims on corporate profits if and when they occur. MSV ignores the risk-reward relation for these two types of economic actors in the operation and performance of business corporations. Instead, based on agency theory, it erroneously assumes that shareholders are the only residual claimants.

The irony of MSV is that, as has been noted above, the public shareholders whom agency theory holds up as the only risk bearers typically never invest in the value-creating capabilities of the company at all. Rather, they purchase outstanding corporate equities with the expectation that while they are holding the shares, dividend income will be forthcoming, and with the hope that when they decide to sell the shares, the stock-market price will have risen to yield a capital gain. Following the directives of MSV, a prime way in which the executives who control corporate resource allocation fuel this hope is by allocating corporate cash to stock buybacks to pump up their company's stock price.

Yet it is the senior executives themselves who are best positioned to gain from these manipulative price increases. Senior executives cause cash flow to be "disgorged" not for the sake of efficient resource allocation, but rather with the goal of increasing their own stock-based pay. ${ }^{108}$ On an increasing scale since the early 2000s, hedge-fund activists have joined with senior executives and their boards in corporate predation, causing the looting of the U.S. business corporation to accelerate. ${ }^{109}$

Why have agency theorists gotten it so wrong? Because they lack a theory of innovative enterprise: a theory of how business organizations transform technologies and access markets to generate products higher in quality and lower in cost than those previously available. Yet these innovative products are the basis of economic growth. Moreover, based on comparativehistorical analysis, I contend that the ways in which innovative enterprises allocate resources and returns provide microfoundations not only for economic growth but also for the employment stability and income equity that are associated with a robust and expanding middle class. ${ }^{110}$

If agency theorists have a coherent theory of the firm, it is the notion that the small, unproductive firm that optimizes subject to given technological and market constraints provides the

108 Hopkins and Lazonick, "The Mismeasure of Mammon."

109 Lazonick and Shin, "Rebalancing Value Creation and Value Extraction."

110 See Lazonick, Competitive Advantage on the Shop Floor; Lazonick, Business Organization and the Myth of the Market Economy; William Lazonick, "Organizational Learning and International Competition," in Jonathan Michie and John Grieve Smith, eds., Globalization, Growth, and Governance, Oxford University Press, 1998: 204-238; Lazonick, "The Theory of the Market Economy"; William Lazonick, "Varieties of Capitalism and Innovative Enterprise," Comparative Social Research, 24, 2007: 21-69; Lazonick, Sustainable Prosperity in the New Economy?; William Lazonick, "Innovative Business Models and Varieties of Capitalism: Financialization of the US Corporation," Business History Review, 84, 4, 2010: 675-702; Inge Lippert, Tony Huzzard, Ulrich Jürgens, and William Lazonick, Corporate Governance, Employee Voice, and Work Organization: Sustaining High Road Jobs in the Automotive Supply Industry, Oxford University Press, 2014: Lazonick, "Labor in the TwentyFirst Century." 
microeconomic foundation for the most efficient economy. Hypothetical firms of this description play the leading role in the absurd theory known as "perfect competition." From such a neoclassical perspective, it is markets, not organizations, that allocate resources to their most efficient uses. Thus, without specifying the value-creation process, Fried and Wang see financial flows of any type as somehow being allocated to more efficient uses. From this perspective, the large corporations that have dominated the U.S. economy for over 100 years are massive "market imperfections." In line with this reasoning, if we want a more efficient economy, corporate executives should be incentivized, as Michael Jensen and his acolytes have told us, to "disgorge the free cash flow."

With its MSV ideology, agency theory is a theory of value extraction without a theory of value creation. It is not surprising, therefore, that Jensen's 1993 American Finance Association presidential address, "The Modern Industrial Revolution, Exit, and The Failure of Internal Control Systems," 111 is, as the title states, all about exiting existing industrial investments, not about entering new ones. Jensen even interprets Joseph Schumpeter's notion of "creative destruction" as being about "efficient exit", i.e., "destruction", ${ }^{112}$ when in fact Schumpeter's entire theoretical orientation was toward the conditions for "entry" through entrepreneurship and innovation: that is, toward the "creative" part of the catchphrase, the part that called for making old ways of doing things obsolete (to which Schumpeter's "destruction" refers). ${ }^{113}$ To understand entry, one needs a theory of innovative enterprise, which is precisely what agency theory lacks.

The Theory of Innovative Enterprise recognizes roles of households acting as taxpayers, workers, consumers, savers, and investors in the value-creation process, and hence provides an economic rationale for their claims on the extraction of value from that process. Through government agencies, households as taxpayers make investments in physical infrastructure and human knowledge without which even, and perhaps especially, the largest business enterprises would not be able to generate competitive products. Hence, through the tax system, the body of taxpayers should get shares of corporate profits if and when they accrue. Through the employment relation, households as workers supply business enterprises with skill and effort that are central to the processes of generating competitive products. Hence, through job stability as well as higher pay and benefits, workers should also share in profits if and when they accrue. Through demand for goods and services, households valorize the products that businesses generate. Hence, households should gain from the innovative capabilities of companies through the production of higher-quality, lower-cost products, which is indeed the purpose of the business corporation.

Finally, The Theory of Innovative Enterprise permits the distinction between investors, who participate in the process of value creation, and savers, who derive incomes from the process of value extraction. Investors in value creation provide financial commitment to industrial enterprises to sustain the development and utilization of productive resources, and hence should receive an equitable share in profits from the generation of competitive products if and when they accrue. In contrast, savers who, as value extractors, use their money to purchase outstanding

\footnotetext{
${ }^{111}$ Michael C. Jensen, "The Modern Industrial Revolution, Exit, and the Failure of Internal Control Systems" Journal of Finance 48, 3, 1993: 831-880.

112 Ibid. 833

113 Joseph A. Schumpeter, Capitalism, Socialism, and Democracy, HarperCollins, 2008 (originally published in 1942) 81-85.
} 
corporate shares without in any way contributing to the value-creation process, should get an income in the form of dividends after all other valid claims of value creators have been paid. In providing financial liquidity, the stock market permits this separation of ownership and control, making savers as passive shareholders able and willing to place their savings in securities in the hope that they will be able to obtain dividends or, if they choose to sell their shares, capital gains.

The theory of the firm that "well-trained" economists, including agency theorists, bring to the policy debate is the antithesis of a theory of innovative enterprise. ${ }^{114}$ With its MSV ideology, agency theory is a theory of value extraction, posing as a theory of value creation. As amply demonstrated since the 1980s, the application of agency theory, with its focus on MSV, undermines the achievement of stable and equitable economic growth. Agency theory is part of the problem, and is in need of a solution.

Innovative enterprise solves the agency problem. By incentivizing and rewarding the real value creators, the innovative enterprise can mobilize the skill, effort, and finance that, by generating high-quality, low-cost products, can improve the performance of the economy-defined in terms of stable and equitable economic growth. The application of innovation theory to corporate governance solves the "agency problem" by setting up governance structures that induce individuals with varied hierarchical responsibilities and functional specialties to work together in business organizations toward the achievement of higher levels of productivity, embodied in higher-quality, lower-cost products. These value-creators share in the gains to innovative enterprise, and they collectively support tax payments as returns for governmental contributions to the value-creation process.

As I have argued elsewhere, the United States can start the transition from the value-extracting economy to the value-creating economy by banning stock buybacks, compensating senior executives for their contributions to the value-creating enterprise, and placing representatives of households as workers and taxpayers on corporate boards. ${ }^{115}$ No progress will be made, however, as long as agency theory with its MSV ideology holds sway. How can academics contribute to the process of putting the United States on a path to achieving stable and equitable growth? The Theory of Innovative Enterprise can help get economic analysis back on track.

\footnotetext{
${ }^{114}$ Lazonick, "Innovative Enterprise or Sweatshop Economics?".

115 Lazonick, "The Value-Extracting CEO."
} 